Illinois State University

ISU ReD: Research and eData

Theses and Dissertations

3-26-2018

\title{
Factors Affecting Illinois Legislators' Perceptions of School-Based Agricultural Education
}

Perry William Harlow

Illinois State University, perryharlow@hotmail.com

Follow this and additional works at: https://ir.library.illinoisstate.edu/etd

Part of the Agriculture Commons, and the Other Education Commons

\section{Recommended Citation}

Harlow, Perry William, "Factors Affecting Illinois Legislators' Perceptions of School-Based Agricultural Education" (2018). Theses and Dissertations. 860.

https://ir.library.illinoisstate.edu/etd/860

This Thesis is brought to you for free and open access by ISU ReD: Research and eData. It has been accepted for inclusion in Theses and Dissertations by an authorized administrator of ISU ReD: Research and eData. For more information, please contact ISUReD@ilstu.edu. 


\title{
FACTORS AFFECTING ILLINOIS LEGISLATORS' PERCEPTIONS OF SCHOOL-BASED AGRICULTURAL EDUCATION
}

\author{
Perry William Harlow
}

104 Pages

This study examined factors contributing to Illinois General Assembly members' perceptions of school-based agricultural education. Personal characteristics and multiple media sources were examined to determine if any of these factors affected their perception of schoolbased agricultural education. These factors included the population area of where the legislator grew up, the population area of the district the legislator represents, the geographical location of the legislator's district, whether the legislator lived on a farm, and whether the legislator worked on a farm. The factors also included frequency of seeing information about school-based agricultural education on multiple media sources including television, radio, newspaper, Facebook, Twitter, Instagram, constituents in school-based agricultural education programs, family and FFA alumni member, Illinois Agricultural Education website, and invitations to school-based agricultural education program events. The sample consisted of 29 subjects.

The data analysis revealed significant results. The geographical location of the legislator's district, seeing information about school-based agricultural education on Facebook and Twitter, and receiving invitations to school-based agricultural education events were factors that contributed to a statistical difference in the results. Legislators from Cook/Collar Counties had a lower perception of school-based agricultural education compared to other location groups. Legislators also tended to have a higher perception of school-based agricultural education if they saw information about school-based agricultural education on Facebook 3-5 times a year. These 
findings have practical implications for school-based agricultural education programs to market themselves to state legislatures better.

KEYWORDS: legislators, agricultural education, perception, factors, funding 
FACTORS AFFECTING ILLINOIS LEGISLATORS' PERCEPTIONS OF SCHOOL-BASED

AGRICULTURAL EDUCATION

PERRY WILLIAM HARLOW

A Thesis Submitted in Partial Fulfillment of the Requirements for the Degree of MASTER OF SCIENCE

Department of Agriculture

ILLINOIS STATE UNIVERSITY 
Copyright 2018 Perry William Harlow 
FACTORS AFFECTING ILLINOIS LEGISLATORS' PERCEPTIONS OF SCHOOL-BASED

AGRICULTURAL EDUCATION

PERRY WILLIAM HARLOW

COMMITTEE MEMBERS:

Richard Steffen, Chair

Maria Boerngen

Lisa Hood 


\section{ACKNOWLEDGMENTS}

I would first and foremost like to thank my advisor, Dr. Richard Steffen, for everything he has done for me throughout my research journey. I know from the bottom of my heart that I could not have done this project without his help. A well-deserved thank you goes out to my other committee members, Dr. Maria Boerngen and Dr. Lisa Hood. Their unique education backgrounds allowed me to see my research through many different lenses.

I would also like to thank the Department of Agriculture faculty and staff at Illinois State University. You have made my time at the University some of the best four years of my life so far. I would especially like to thank my work mom, Kathy Scott, for all of the love and support she provided to me. My time at Illinois State University would have been very different if it wasn't for you.

For all the times I needed to cry, laugh, or vent about a class project, I always knew my officemates would be there for me. I am forever grateful for Caleb Wepprecht, Theoneste Nzaramyimana, and Jacob Donohoe. I could not have asked for better officemates!

A special thank you needs to be directed towards Dr. Wm. Jay Jackman. Jay, you gave me an opportunity to advocate for agricultural education in Washington, D.C. and that experience changed my life. The internship encouraged me to look more into public policy as a career and because of that, you helped me find my true calling. I cannot thank you enough for giving me that opportunity. I also would like to thank U.S. Senator Tammy Duckworth and her staff for my time as an intern.

I need to send a special thanks to all the brothers in my life for encouraging me to drive forward when I wanted to stop. Christian Lovell, Robert Partyka, Riley Hintzsche, Austin Miller, Jeff Sherman, Jake Bradford, Daniel Patton, Chris Steppig, and so many more. You all 
helped me grow as a person during my time in graduate school, and I am so blessed to be friends with every single one of you.

To all my best friends, I cannot thank you enough for always being there for me. You were always one phone call away for help with my homework or eat Chinese takeout with me. Thank you to Dakota, Courtney, Brad, Sam P., Sam D., Larissa, Melanie, Tammy, Phillip, Mykalya, Marla, Abby, Lexie, my HOBY family, and so many others. I cannot thank you enough for all of the memories I made with you at ISU.

And finally, I want to thank my family. To my parents and the most prominent role models in my life, Mark and Doreen Harlow. Thank you for always pushing me to do bigger and better things with my life. Both of you taught me to be kind to others and listen to the past so you can plan for the future. You always told me to say, "Please and thank you and learn a lot" and I still carry that with me to this day. To my sister, Kaitlyn Harlow. Sometimes I love you and some days I hate you, but at the end of the day, I know you will always be there for me. To my Aunt Char, you always pushed me to go above, and beyond and I resented every time I hung out with you. Looking back, I know you were trying to make me a better person, and I love you for that. Thank you to my Grandma Rita for always supporting me at my school events. Thank you to Grandma and Grandpa Harlow for showing me what a strong work ethic is and teaching me to never to quit until the job is done correctly.

P. W. H. 


\section{CONTENTS}

Page

ACKNOWLEDGMENTS

$\begin{array}{ll}\text { CONTENTS } & \text { iii }\end{array}$

TABLES vii

FIGURES

CHAPTER I: INTRODUCTION 1

Statement of the Problem $\quad 2$

$\begin{array}{ll}\text { Theoretical Framework } & 3\end{array}$

Symbolic Interactionism 3

$\begin{array}{ll}\text { Perception } & 4\end{array}$

Significance of Study $\quad 5$

Statement of Purpose $\quad 5$

$\begin{array}{ll}\text { Research Questions } & 5\end{array}$

$\begin{array}{ll}\text { Research Hypotheses } & 6\end{array}$

$\begin{array}{ll}\text { Scope of the Study } & 8\end{array}$

$\begin{array}{ll}\text { Assumptions } & 9\end{array}$

$\begin{array}{ll}\text { Limitations } & 9\end{array}$

Definition of Terms $\quad 9$

CHAPTER II: LITERATURE REVIEW 11

Evolution of the Agricultural Industry in the United States 11

History of Agricultural Education and the National FFA Organization 12

Changes in School-Based Agricultural Education Curriculum 14 
Funding for School-Based Agricultural Education

History of the Illinois Agricultural Education Line Item

Previous Research about Legislative Decision-Making

Related Perceptual Studies of Agriculture and Agricultural Education

Summary

Rationale

Participants

$\begin{array}{ll}\text { Instrumentation } & 25\end{array}$

$\begin{array}{ll}\text { Data Collection for Quantitative Questionnaire } & 28\end{array}$

$\begin{array}{ll}\text { Data Collection for Qualitative Interviews } & 29\end{array}$

$\begin{array}{ll}\text { Data Analysis } & 30\end{array}$

$\begin{array}{ll}\text { Quantitative Statistical Analysis } & 31\end{array}$

$\begin{array}{ll}\text { Qualitative Data Analysis } & 32\end{array}$

$\begin{array}{ll}\text { Summary } & 33\end{array}$

$\begin{array}{ll}\text { CHAPTER IV: RESULTS } & 34\end{array}$

Research Question One 35

$\begin{array}{ll}\text { Null Hypothesis } 1 & 35\end{array}$

Null Hypothesis $2 \quad 36$

$\begin{array}{ll}\text { Null Hypothesis } 3 & 36\end{array}$

$\begin{array}{ll}\text { Research Question Two } & 39\end{array}$

$\begin{array}{ll}\text { Null Hypothesis } 4 & 39\end{array}$

$\begin{array}{ll}\text { Null Hypothesis } 5 & 39\end{array}$ 
Null Hypothesis 6

Research Question Three

Null Hypothesis 7

Null Hypothesis 8

Null Hypothesis 9

Null Hypothesis 10

Null Hypothesis 11

Null Hypothesis 12

Null Hypothesis 13

Null Hypothesis 14

Null Hypothesis 15

Null Hypothesis 16

Research Question Four

Null Hypothesis 17

Null Hypothesis 18

Research Question Five

Null Hypothesis 19

Null Hypothesis 20

Qualitative Interview Questions

Agriculture is Food Production

Urban Agriculture is Gardening

Agriculture is Not an Urban Issue

Farm Economy was Shaky 
$\begin{array}{ll}\text { Summary } & 64\end{array}$

CHAPTER V: DISCUSSION \& RECOMMENDATIONS 65

$\begin{array}{ll}\text { Discussion } & 65\end{array}$

$\begin{array}{ll}\text { Research Question } 1 & 65\end{array}$

$\begin{array}{ll}\text { Research Question } 2 & 66\end{array}$

$\begin{array}{ll}\text { Research Question } 3 & 68\end{array}$

$\begin{array}{ll}\text { Research Question } 4 & 70\end{array}$

$\begin{array}{ll}\text { Research Question } 5 & 71\end{array}$

$\begin{array}{ll}\text { Recommendations } & 72\end{array}$

Recommendations for Marketing School-Based Agricultural Education Programs to

$\begin{array}{ll}\text { Legislators } & 72\end{array}$

$\begin{array}{ll}\text { Recommendations for Future Research } & 74\end{array}$

$\begin{array}{ll}\text { Summary } & 74\end{array}$

$\begin{array}{ll}\text { REFERENCES } & 76\end{array}$

$\begin{array}{ll}\text { APPENDIX A: IRB APPROVAL } & 83\end{array}$

$\begin{array}{ll}\text { APPENDIX B: COVER LETTER } & 84\end{array}$

APPENDIX C: QUESTIONNAIRE CONSENT 85

$\begin{array}{ll}\text { APPENDIX D: CONSENT FOR INTERVIEW } & 87\end{array}$

$\begin{array}{lr}\text { APPENDIX E: QUESTIONNAIRE } & 88\end{array}$

$\begin{array}{ll}\text { APPENDIX F: INTERVIEW QUESTIONS } & 97\end{array}$

APPENDIX G: INTERVIEW RESPONSES 99

$\begin{array}{ll}\text { APPENDIX H: QUESTIONNAIRE PERMISSION } & 103\end{array}$ 


\section{TABLES}

Table

Page

1. Participant's Characteristics Compared to NCSL Characteristics

2. Hypothesis 1 Results: Where the Legislator Grew Up and the Legislator's Perception of Agriculture

3. Hypothesis 2 Results: The Legislators' District and the Legislators' Perception of Agriculture

4. Hypothesis 3 Results: Geographical Location of Legislators' District and Legislators' Perception of Agriculture

5. Pairwise Differences between Cook County/Collar Counties and South of Interstate 80 and North of Interstate 70 and Legislators' Perception of Agriculture

6. Hypothesis 4 Results: Where the Legislators Grew Up and the Legislators' Perception of School-Based Agricultural Education

7. Hypothesis 5 Results: The Legislators' District and the Legislators' Perception Of School-Based Agricultural Education

8. Hypothesis 6 Results: Geographical Location of Legislators' District and Legislators' Perception of School-Based Agricultural Education

9. Pairwise Differences between Cook County/Collar Counties group and South of Interstate 80 and North of Interstate 70 group and the Legislators' Perception Of School-Based Agricultural Education

10. Pairwise Differences between West of Illinois Route 47 and North of Interstate 80 group and South of Interstate 80 and North of Interstate 70 group and Legislators' Perceptions of School-Based Agricultural Education 
11. Hypothesis 7 Results: Seeing Information about School-Based Agricultural Education on the Television

12. Hypothesis 8 Results: Hearing Information about School-Based Agricultural Education on the Radio

13. Hypothesis 9 Results: Seeing Information about School-Based Agricultural Education in the Newspaper

14. Hypothesis 10 Results: Seeing Information about School-Based Agricultural Education on Facebook

15. Pairwise Differences between Seeing Information about School-Based Agricultural Education "None at All" and "Rarely" on Facebook

16. Pairwise Differences between Seeing Information about School-Based Agricultural Education "None at All" and "Occasionally" on Facebook

17. Hypothesis 11 Results: Seeing Information about School-Based Agricultural Education on Twitter

18. Pairwise Differences between Seeing Information about School-Based Agricultural Education "None at All" and "Rarely" on Twitter

19. Hypothesis 12 Results: Seeing Information about School-Based Agricultural Education on Instagram

20. Hypothesis 13 Results: Receiving Information about School-Based Agricultural Education from Constituents in School-Based Agricultural Education Programs 
21. Hypothesis 14 Results: Receiving Information about School-Based Agricultural Education from Family Members and FFA Alumni Members Involved in School-Based Agricultural Education Programs

22. Hypothesis 15 Results: Receiving Information about School-Based Agricultural Education from the Illinois Agricultural Education Website

23. Hypothesis 16 Results: Receiving Invitations to School-Based Agricultural Education Activities

24. Pairwise Differences between Receiving Invitations to School-Based Agricultural Education Events "None at All" and "Rarely"

25. Pairwise Differences between Receiving Invitations to School-Based Agricultural Education Events "None at All" and "Occasionally"

26. Hypothesis 17 Results: Lived on a Farm to their Perception of Agriculture

27. Hypothesis 18 Results: Worked on a Farm to their Perception of Agriculture

28. Hypothesis 19 Results: Lived on a Farm to their Perception of School-Based Agricultural Education

29. Hypothesis 20 Results: Worked on a Farm to their Perception of School-Based Agricultural Education

30. Statements of Each Theme of Focus Groups 


\section{FIGURES}

Figure $\quad$ Page

1. School-Based Agricultural Education Three Component Model 13

2. Explanatory Sequential Mixed Methods Design 25 


\section{CHAPTER I: INTRODUCTION}

School-based agricultural education has been around since 1917 when the Smith-Hughes National Vocation Education Act was created ("Smith-Hughes National Vocational Education Act of 1917," 1917). This funding gave the opportunity for young male farmers to learn more about agriculture so they could return to their family farm and farm with their father (Hillison, 1996). This new school program led to the creation of the Future Farmers of America group that was founded in 1928 ("FFA History," n.d.).

Elected officials believed that school-based agricultural education was very beneficial for students, so they allocated funding to support local agriculture programs (Novel, 2009). This funding is now known as Carl D. Perkins grant money. Some states like Illinois also believed that school-based agricultural education was important for school-aged students, so they decided to fund agriculture programs at the state level (Bidner, 1987). In 1987, the first agricultural education line item was approved in the Illinois state budget for \$48,500 ("ILCAE \& ICAE," n.d.).

In recent years, the agricultural education line item has been zeroed-out in the state budget, but advocates for agricultural education convinced the state legislators to put the funding back in the state budget (Berg, 2016; Hoffman, 2015). The line-item being zeroed out was very concerning for agricultural education supporters as this continued to happen. Many factors contribute to a legislator's policy decision, but some include the home district of the legislator, gender, and the type of constituency represented (Patterson, 1983; Wirt, Morey, \& Brakeman, 1970). However, advocates for agricultural education do not know which factors contributed to the decision to zero out the line item. 
There is a substantial amount of research about factors that contribute to a legislator's policy decision (Hirschi, 1969; Mazzoni, Sullivan, \& Sullivan, 1983; Patterson, 1983; Robertson, Durtan, \& Barham, 1992; Wirt et al., 1970) but very little of the literature actually uses those factors to ask legislators about their policy decisions. Previous research looked at asking legislators about their perception of different organizations and government services, but there is no research looking at the factors that affect an elected official's perceptions of school-based agricultural education.

\section{Statement of the Problem}

There are fewer people than ever working in production agriculture; $1.9 \%$ of the nation's labor force is employed in agriculture (Dimitri, Effland, \& Conklin, 2005). More people are moving to urban areas and leaving rural areas ("World's population increasingly urban with more than half living in urban areas," 2014). People who live in urban and rural areas have different views on agriculture and school-based agricultural education. Wachenheim and Lesch (2002) surveyed Illinois residents about their perception of agriculture as an important part of the state's economy. The response varied based on the distance of the respondents from a major population center (defined as 100,000 people or more). In counties containing, or adjacent to, a major population center, agriculture was ranked in the bottom half of the industries. However, respondents who are involved in production agriculture ranked it as more important. If the urban population no longer values school-based agricultural education program, then their legislators who represent them may not be compelled to value school-based agricultural education either.

With Chicago being the largest city in Illinois, a large percentage of the elected officials also come from there. These groups of legislators can control the outcomes of many issues in the state legislature. It is essential to know what factors are contributing to their perceptions of 
school-based agricultural education because that affects their decision on policy issues. Very few studies have looked at the attitudes and perception of agriculture from the lenses of an elected official, but there is no research looking at their views of school-based agricultural education. This is a problem because there is no research to guide how school-based agricultural education programs should be marketing themselves to local elected officials because they provide program funding.

\section{Theoretical Framework}

\section{Symbolic Interactionism}

Symbolic interaction is one of the many theories in social science. Some of the beginning scientists of this theory included George Herbert Mead, John Dewey, W.I. Thomas, Robert E. Park, William James, and many more (Blumer, 1969). Herbert Blumer coined the term "symbolic interactionism" in an article written in 1937 (Blumer, 1969). Blumer believed that three premises or principles explained the meaning of symbolic interactionism. Blumer (1969) stated:

"The first premise is that human beings act towards things on the basis of the meanings that the things have for them. The second premise is that the meaning of such things is derived from, or arises out of, the social interactions that one has with one's fellow. The third premise is that these meanings are handled in, and modified through, an interpretive process used by the person in dealing with the things he encounters." (p. 2)

These premises identified by Blumer can be categorized into three core areas: meaning, language, and thinking (Aksan, Kisac, Aydin, \& Demirbuken, 2009). 


\section{Perception}

Perception is a way of regarding, understanding or interpreting something. The term perception has been defined in many ways by a plethora of authors, but the basic concept of all definitions has been similar. Matlin (1983) has identified perception as a way information is gathered and interpreted. Everything an individual knows about something or someone is based on the perceptual information. Methods of studying perception range from essentially biological or physiological approaches, through psychological approaches, to the often-abstract thought experiments of mental philosophy (Ivancevic, Jovanocis, Jovanovic, Djukic, \& Lukman, 2011).

Vanderveer (1980) said perception is influenced by the perceiver, the target, and the situation. The researcher also stated that the factors in the perceiver are attitudes, motives, interests, experienced, and expectation. Vanderveer continued to indicate that there are several characteristics and beliefs of the perceivers affecting perception:

Projection - attributing one's own characteristics to other people,

Selective perception - people selectively interpret what they see on the basis of their interest, background, experience, and attitudes,

Stereotyping - judging someone on the basis of one's perception of the group to which that person belongs,

Halo effect - drawing a general positive impression about an individual on the basis of a single characteristic,

Contrast effect - evaluating a person's characteristics that are affected by comparisons with other people recently encountered who rank higher or lower on the same characteristics, and Horn effect - drawing a general negative impression about an individual on the basis of a single characteristic. 


\section{Significance of Study}

This study will give advocates for school-based agricultural education a better look at the factors that affect the Illinois General Assembly's view of school-based agricultural education. This study will also help local school-based agricultural education teachers market their programs more efficiently to elected officials in the community. In addition, this research will give some perspective on how often elected officials rely on media to help them gain knowledge on topics of school-based agricultural education.

\section{Statement of Purpose}

The primary purpose of this study was to determine the demographic and media source factors that contribute to the state legislator's perception of school-based agricultural education.

\section{Research Questions}

Five research questions that guided the inquiry for this study were:

1. Is there a relationship between the demographics of the legislators on their perception of agriculture?

2. Is there a relationship between the demographics of the legislators on their perception of school-based agricultural education?

3. Is there a relationship between how often the legislators hear, see, or read something about school-based agricultural education on their perception of school-based agricultural education?

4. Is there a relationship between the legislator's background experiences with farming on their perception of agriculture?

5. Is there a relationship between the legislator's background experiences with farming on their perception of school-based agricultural education? 


\section{Research Hypotheses}

The following three hypotheses relating to the research question one were set forth in the null form to facilitate significance testing.

$\mathrm{H}_{01}$ : There is no significant difference in the legislators' perceptions of agriculture based on where they grew up.

$\mathrm{H}_{02}$ : There is no significant difference in the legislators' perceptions of agriculture based on the population area of the legislators' district.

$\mathrm{H}_{03}$ : There is no significant difference in the legislators' perceptions of agriculture based on the geographical location of the legislators' district.

The following three hypotheses relating to research question two were set forth in the null form to facilitate significance testing.

$\mathrm{H}_{04}$ : There is no significant difference in the legislators' perceptions of school-based agricultural education based on where they grew up.

$\mathrm{H}_{05}$ : There is no significant difference in the legislators' perceptions of school-based agricultural education based on population area of the legislators' district.

$\mathrm{H}_{06}$ : There is no significant difference in the legislators' perceptions of school-based agricultural education based on the geographical location of the legislators' district.

The following ten hypotheses relating to research question three were set forth in the null form to facilitate significance testing.

$\mathrm{H}_{07}$ : There is no significant difference in the legislators' perceptions of school-based agricultural education based on seeing information about school-based agricultural education on the television. 
$\mathrm{H}_{08}$ : There is no significant difference in the legislators' perceptions of school-based agricultural education based on hearing information about school-based agricultural education on the radio.

$\mathrm{H}_{09}$ : There is no significant difference in the legislators' perceptions of school-based agricultural education based on seeing information about school-based agricultural education in the newspaper.

$\mathrm{H}_{10}$ : There is no significant difference in the legislators' perceptions of school-based agricultural education based on seeing information about school-based agricultural education on Facebook.

$\mathrm{H}_{11}$ : There is no significant difference in the legislators' perceptions of school-based agricultural education based on seeing information about school-based agricultural education on Twitter.

$\mathrm{H}_{12}$ : There is no significant difference in the legislators' perceptions of school-based agricultural education based on seeing information about school-based agricultural education on Instagram.

$\mathrm{H}_{13}$ : There is no significant difference in the legislators' perceptions of school-based agricultural education based on receiving information from constituents in school-based agricultural education programs.

$\mathrm{H}_{14}$ : There is no significant difference in the legislators' perceptions of school-based agricultural education based on receiving information from family members and FFA alumni members about school-based agricultural education. 
$\mathrm{H}_{15}$ : There is no significant difference in the legislators' perceptions of school-based agricultural education based on receiving information from the Illinois Agricultural Education website.

$\mathrm{H}_{16}$ : There is no significant difference in the legislators' perceptions of school-based agricultural education based on receiving invitations to school-based agricultural education activities.

The following two hypotheses relating to research question four were set forth in the null form to facilitate significance testing.

$\mathrm{H}_{17}$ : There is no significant difference in the legislators' perceptions of agriculture based on whether the legislator lived on farm.

$\mathrm{H}_{18}$ : There is no significant difference in the legislators' perceptions of agriculture based on whether the legislator worked on a farm.

The following two hypotheses relating to research question five were set forth in the null form to facilitate significance testing.

$\mathrm{H}_{19}$ : There is no significant difference in the legislators' perceptions of school-based agricultural education based on whether the legislator lived on a farm.

$\mathrm{H}_{20}$ : There is no significant difference in the legislators' perceptions of school-based agricultural education based on whether the legislator worked on a farm.

\section{Scope of the Study}

The scope of this study included members of the $100^{\text {th }}$ Illinois General Assembly that served from 2016-2018. The legislators currently serving in the state legislature will give the researchers the most recent perception of school-based agriculture education. 


\section{Assumptions}

This study included the following assumptions:

1. Only legislators completed the questionnaire.

2. The participants will answer the questionnaire and interviews questions honestly and candidly.

\section{Limitations}

There were some unavoidable limitations while conducting the research. First, this research had a low response rate among the members of the Illinois General Assembly. Therefore, it would not be possible to generalize the results for the entire group. An election cycle was happening during the timing of this research which may have caused a low response rate among the participants due to their busy schedules. Due to the questionnaire using Likerttype questions, these questions forced participants into particular response categories, limiting the range of responses.

\section{Definition of Terms}

The following terms were defined operationally for use in this study:

- School-based agricultural education: formal agricultural education programs offered in the public schools (as opposed to non-formal agricultural education programs offered by businesses or other non-school agencies) (Phipps, Osborne, Dyer, \& Ball, 2008)

- Legislator: a member of the General Assembly. A legislator is a Senator if he or she is a member of the Senate or a Representative if he or she is a member of the House of Representatives. ("Illinois Legislative Glossary," n.d.) 
- General Assembly (Legislature): the branch of State government responsible for enacting laws. In Illinois, legislative power is vested in the General Assembly. ("Illinois Legislative Glossary," n.d.) 


\section{CHAPTER II: LITERATURE REVIEW}

\section{Evolution of the Agricultural Industry in the United States}

The agricultural industry has revolutionized the United States over the past 250 years. Modern agriculture began in the 17th century when farmers near water access grew cash crops for trade ("Historical Timeline--17th-18th Centuries," 2014). Almost 200 years later in 1793, Eli Whitney patented the cotton gin that separated cotton from its seeds (Brodski Schur, 2016). Four years later, Charles Newbold patented the first cast-iron plow, and Jethro Wood patented the iron plow with interchangeable parts in 1819 ("Historical Timeline--Farm Machinery and Technology," 2014). During the mid-1800's, the wheat-growing industry began and started to move westward towards states of Minnesota, Kansas, and Illinois (Keller \& Bishop, 1912). Most of the land before the 1890's was plowed by hand or horsepower, but the invention of the steam tractor by John Froelich transformed the agriculture industry in 1892 (Oden, 2009).

At the turn of the century, extensive experimental projects began to breed diseaseresistant varieties of plants to help improve plant yield and quality (Biffen, 1905). During 191020, large open-geared gas tractors were introduced to sections of the United States with extensive farming (The Story of U.S. Agricultural Estimates, 1969). The number of acres fell by the thousands for cereal crops in the 1940's because fewer people were using horses and mules for power and began using tractors ("Historical Timeline--Crops and Livestock," 2014). During this time, there was an increased use of herbicides and pesticides (Timmons, 1970). The number of tractors outnumbered the number of horses and mules used for work power on the farm by 1960 (Dimitri et al., 2005). Molecular biologist, Paul Berg, introduced new techniques that transferred the genes from one strand of DNA to another in the 1970's ("Paul Berg - Biographical," 2014). The first genetically modified food, the FLAVRSVRTM tomato, was approved by the United 
States Food and Drug Administration in 1994 and information technology and precision techniques are more used by farmers than before (Bruening \& Lyons, 2000).

\section{History of Agricultural Education and the National FFA Organization}

One of the first agriculture clubs that began building the foundation for agricultural education were corn clubs (Uricchio, Moore, \& Coley, 2013). Corn clubs were local organizations consisting of only boys who grew corn on an acre of land under the supervision of a local club leader (Uricchio et al., 2013). These clubs increased the demand for agricultural education in public schools and influenced the development of the National FFA Organization and 4-H Youth Development Organization (Uricchio et al., 2013).

In 1917, federal legislation was created to help promote and fund vocational agricultural education curriculum in high schools (Carleton, 2002). This legislation was The Smith-Hughes Vocational Education Act of 1917. The funding was created to aid in the classroom instruction component of the three-circle model. There is not an exact date of when the integrated threecircle model of agricultural education was implemented, but historians estimate it was around the time of the Smith-Hughes Act (Croom, 2008). Figure 1 demonstrates the structure of the threecircle model.

The model for organizing instruction in school-based agricultural education involves the interrelationships between three major concepts: classroom and laboratory instruction, supervised agricultural experience, and agricultural youth organization participation (Phipps et al., 2008). Classroom and laboratory instruction are those activities that provide learning experiences within the confines of a school facility (Croom, 2008). Supervised Agricultural Experience (SAE) is an independent learning program for students enrolled in agricultural education courses designed to provide a learning experience for students in the agricultural 
career pathway of their choice (Croom, 2008). The agricultural youth organization (FFA) assists in the development of the students' interests in agricultural careers through the support of the SAE program (Croom, 2008).

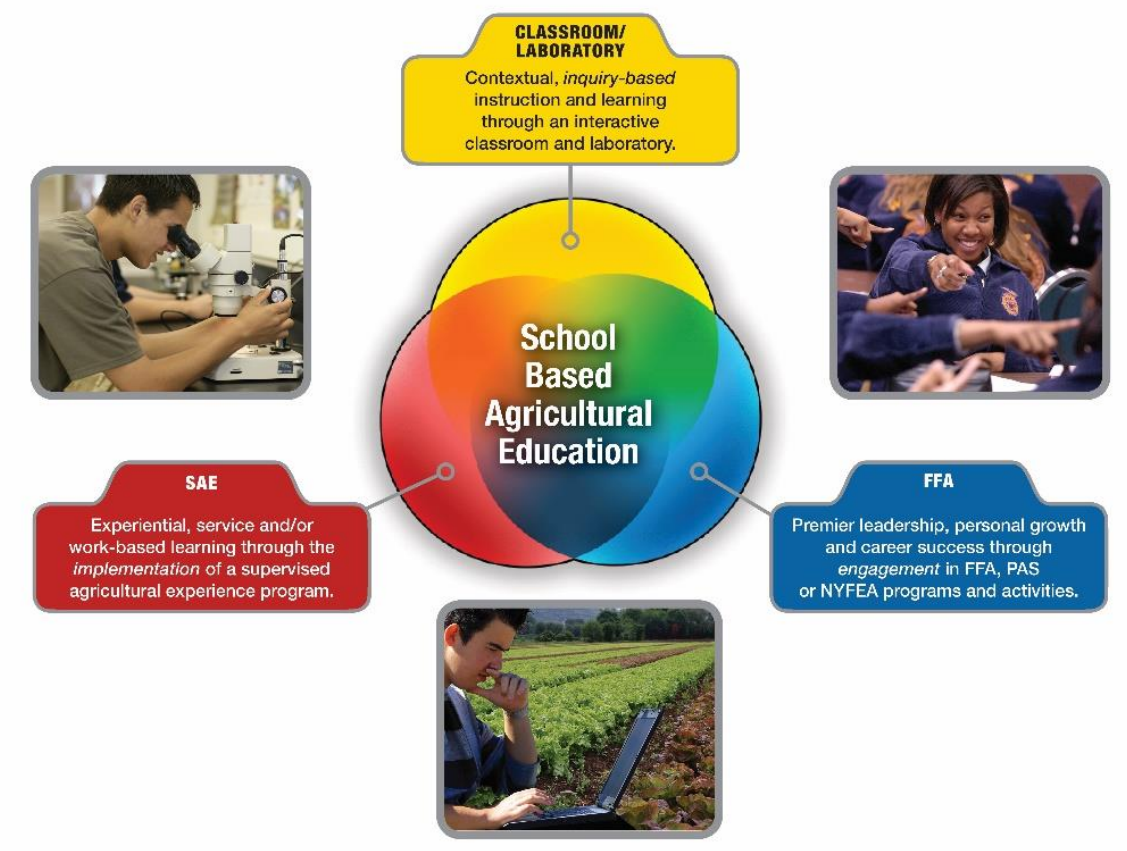

Figure 1: School-Based Agricultural Education Three-Component Model

One part of the three-circle model included FFA. In 1928, 33 students from 18 states established the Future Farmers of America to provide leadership training for farm boys ("National FFA Organization Records, 1916-2008," 2017). At the third national convention, the membership decided that only boys were allowed to join the group and the creed and colors were adopted ("National FFA Organization Records, 1916-2008," 2017). The nationally-recognized blue corduroy jackets were adopted as the organization's official dress in 1933 ("National FFA Organization Records, 1916-2008," 2017). 
In 1965, the New Farmers of America, the organization for African-American agricultural students, merged with the Future Farmers of America ("National FFA Organization Records, 1916-2008," 2017). It was not until 1969 that women were allowed to become Future Farmer of America members, hold office and participate in competitive events ("National FFA Organization Records, 1916-2008," 2017). Fred McClure became the organization’s first African-American National Officer in 1974, and Jan Eberly became the first female National FFA President in 1982 ("National FFA Organization Records, 1916-2008," 2017). In 1988, the Future Farmers of America changed its name to the National FFA Organization to reflect the growing diversity in the industry of agriculture ("National FFA Organization Records, 19162008," 2017). At this same convention, seventh and eighth-grade students were permitted to become FFA members. Chapters in the Virgin Islands and Guam, along with five chapters in Micronesia, were chartered as well ("FFA History," n.d.). At the National FFA Convention in 2016, the Committee for Clarification of Official Dress and Related Policies recommended that women be allowed to wear black slacks or a black skirt for Official Dress and transgender individuals may be allowed to wear the Official Dress for the gender with which they identify (Millspaugh, 2016). The policies changes with the National FFA Organization demonstrate the growth of the organization over the past eighty years.

\section{Changes in School-Based Agricultural Education Curriculum}

Agricultural education curriculum has radically changed over the past 125 years. Early agricultural education curriculum fitted the needs of students who were preparing to work on the farm after high school ("Smith-Hughes National Vocational Education Act of 1917," 1917). It was not until 1978 that The Vocational Education Act of 1976 established the community schools concept and the basic skills program (J. L. Scott \& Sarkees-Wircenski, 2004). This amendment 
to the legislation aimed at improving student achievement in reading, mathematics, and written and oral communication. In 1984, The Carl D. Perkins Vocational Education Act looked at expanding, improving, modernizing, and developing quality vocational education programs to meet the needs of the workforce and promote economic growth (J. L. Scott \& SarkeesWircenski, 2004). This new legislation put a lot of pressure on the vocational programs to redesign their curriculum to fit the needs of the industry. In 2006, the reauthorization of The Carl D. Perkins Career and Technical Education Act focused on the academic achievement of career and technical (CTE) education students, strengthening the connection between secondary and post-secondary education, and improving state and local accountability (J. L. Scott \& Sarkees-Wircenski, 2004).

The origins of agriscience occurred during the late 1880's in the United States with the creation of The Hatch Act of 1887. The Hatch Act of 1887 provided annual funding to support state agricultural experiment stations in each state in conjunction with the land-grant university ("Hatch Act of 1887," 2017). From the time of the passage of the 1887 Act until the passage of The Smith-Hughes Act in 1917 a close working relationship existed between agricultural education and the Department of Agriculture which administered The Hatch Act. (Hillison, 1996). Even though the Federal Board of Vocational Education had federal oversight authority for agricultural education as mandated by The Smith-Hughes Vocational Education Act of 1917, the United States Department of Agriculture still assisted until 1929 (Hillison, 1996). The preamble of The Hatch Act stated its stance on agricultural science:

"Be it enacted by the Senate and House of Representatives of the United States of America in Congress assembled, that in order to aid in acquiring and diffusing among the people of the United States useful and practical information on subjects connected with 
agriculture, and to promote scientific investigation and experiment respecting the principles and applications of agricultural science, there shall be established, under direction of the college or colleges or agricultural department of colleges in each State or Territory a department known and designated as an "experiment station"” ("Hatch Act of $1887, " 2017)$.

Federal career and technical education policy changed very little from The Smith-Hughes Act of 1917 to The Carl D. Perkins Vocational Technical Education Act of 1984. During this time frame, vocational education policy maintained its focus on preparing entry-level workers with little to no emphasis on academic skill preparation. The Perkins Act of 1984 put pressure on career and technical education to improve their curriculum design to meet the needs of the industry's demand.

In 1988, the National FFA Organization introduced the Agriscience Student Recognition Program ("FFA History," n.d.). This program awarded students for researching science-based agricultural problems. Since the creation of the program, it has gone through many modifications and is still utilized in the organization today.

In the early to mid-2000's, agricultural education teachers saw a need to improve their curriculum. The National Council of Agricultural Education (NCAE) established a long-range goal for agricultural education to increase growth and quality of programs (Understanding the CASE Model, 2012). NCAE decided to create a new curriculum called Curriculum for Agricultural Science Education (CASE). The CASE project was established to provide a structured sequence for courses, but CASE also served as a model for elevating the level of rigor and relevance expected for the new vision of agricultural education (Understanding the CASE Model, 2012). The rigor of CASE was validated by the alignment of lessons with national 
standards for agriculture, science, math and English language arts (Understanding the CASE Model, 2012). For connection of relevance with student learners, the CASE curriculum highlights the strengths of experiential learning, the heart and soul of agricultural education, by utilizing activity-, project-, and problem-based instructional strategies (Understanding the CASE Model, 2012).

\section{Funding for School-Based Agricultural Education}

There are two primary ways that agricultural education is funded: federal and state. At the federal level, agricultural education funding is available through The Carl D. Perkins Career and Technical Education Act (Perkins). For the fiscal year 2018, the proposed funding for Perkins was $\$ 1.118$ billion. The funding for Career and Technical Education (CTE) was determined by the congressmen and woman who serve on the House Labor, Health, and Human Services and Education subcommittee in the House Committee on Appropriations. They approve of the legislation for the education funding bill.

Funding for CTE is also available at the local level. In Illinois, there is CTE funding available from the State Board of Education. In the fiscal year 2018 budget proposed by the Governor, there was $\$ 32,062,100$ available for CTE programs (Illinois State Budget: Fiscal Year 2018, 2017). Funding for CTE depends on the proposed budget from the governor as well as budget amendments from the Illinois General Assembly.

Illinois agricultural education has had a line item in the state budget for the past 30 years. In 1987, the first agricultural education line item within the Illinois State Board of Education budget was approved at $\$ 48,500$ ("ILCAE \& ICAE," n.d.). When the line item was increased to $\$ 1,000,000$ in 1989, the Facilitating Coordination in Agricultural Education Project (FCAE) was established to assist in the coordination of improvement and expansion efforts in agricultural 
education ("ILCAE \& ICAE," n.d.). The current level for the agricultural education line item is \$5,000,000 (FY17 Final Appropriations and FY18 Enacted Appropriations, 2017; Illinois State Budget: Fiscal Year 2018, 2017). The agricultural education line item has fluctuated over the years. The highest line item funding was $\$ 5,000,000$ in 2018 , and the lowest funding was $\$ 48,500$ in 1987 . In recent years, the agricultural education line item has been cut, but agricultural education advocates successfully put the funding back into the budget (Berg, 2016; Hoffman, 2015).

\section{History of the Illinois Agricultural Education Line Item}

A group of agriculture professionals realized that there was a need for a group of people that will be a loud voice for agricultural education at the state level. This group saw an increasing demand for trained and qualified individuals to perform tasks in the new, modern agriculture industry. On December 13, 1984, the Illinois Leadership Council for Agricultural Education (ILCAE) was formed (Bidner, 1987). ILCAE was developed through a "grassroots movement" as they noted Illinois citizens were concerned over the neglect of educating people about agriculture (Bidner, 1987). The group membership consists of representation from "all levels of agricultural business, industry, and labor, as well as agricultural organizations, commodity groups and governmental agencies" (Bidner, 1987). There are eight key segments of agriculture education that ILCAE believed to be the top priorities in 1987. The eight key sections were: agricultural basics in education (Ag in the Classroom), K-8 exploration of agricultural careers, secondary agricultural education programs, post-secondary agricultural education programs, baccalaureate and graduate education in agriculture, agriculture teacher education, adult education in agriculture, and state leadership for agriculture education (Bidner, 1987). 
To address the critical segments, ILCAE believed there must be state funding for agricultural education in the state budget. State Representative Gordon Ropp (R-Normal) introduced an amendment to House Bill 3091 for $\$ 5,000,000$ to be allocated for the agricultural education line. House Bill 3091 was passed and sent over to the Senate. The Senate took out the \$5,000,000 out of House Bill 3091 and replaced \$48,500 in House Bill 3090. House Bill 3090 was signed by Governor James Thompson on December 5th, 1986 and became Public Act (841191). In this public act, it allocated $\$ 48,500$ for agricultural education in Illinois.

\section{Previous Research about Legislative Decision-Making}

Policy makers in state legislatures may be influenced by many sources (Patterson, 1983). Researchers from the University of Idaho identified three variables affecting voting behavior: a) personal characteristics or affiliations including political party, age, gender, socioeconomic background, seniority and committee membership; b) the home district of the legislator; and c) the type of constituency represented in terms of urban-rural, agricultural-industrial, ethnicreligious, and affluent versus poor (Wirt et al., 1970). Patterson identified six sources of influence including a) party and party leaders, b) committees, c) staff, d) lobbyists, e) the governor and f) a legislator's constituents. These sources were not ranked in any order.

In a study of the effectiveness of state-level education lobbying strategies in Minnesota, researchers asked legislators to identify what factors influenced their educational policy decision (Mazzoni et al., 1983). Legislators indicated that they give weight to personal feelings, constituent desires, recommendations of colleagues, staff recommendations, interest groups views, and recommendations of friends when making decisions about school issues. Robertson, Durtan, and Barnham (1992) studied selected influences on voting decisions of the Virginia General Assembly. They found legislators ranked their personal views as having the strongest 
impact on their voting behavior followed by constituents, interest groups and colleagues in the legislature next, and staff last.

Hirschi (1969) researched selected variables associated with personal characteristics and affiliations to determine if a relationship with voting behavior existed. The researcher concluded legislators who were most likely to support education-related legislation would: a) be older and have more legislative experience; b) be actively involved in school-related activities; c) represent a large population of school-aged students from rural districts; d) express religious affiliation, except those belonging to the Catholic faith; e) be employed as a professional, semi-professional, or a salesman; and f) serve on a major legislative committee, but not in a leadership position.

\section{Related Perceptual Studies of Agriculture and Agricultural Education}

Blezek and Dillon (1991) researched the perceptions of agribusiness leaders towards agricultural education in Nebraska. The researchers surveyed 264 agribusiness and agricultural education leaders in Nebraska and asked if they believed that the Nebraska Department of Education and the Agricultural Education Department at the University of Nebraska-Lincoln were providing effective leadership to agricultural education programs in Nebraska's schools. Of these surveys, one fourth rated the Agriculture Education Division of the Nebraska State Department of Education as very effective while over half (53\%) rated it as somewhat effective. Six percent of the total sample rated it as not effective at all. Of those rating the Agriculture Education Division of the State Department of Education as not at all effective, the most frequent reason given was the loss of funding by the Division. Fifty-nine percent of both education and agribusiness leaders would support a change in how money is allocated to vocational education in agriculture. 
Scott and Lavergne (2004) researched the perception of high school freshman regarding the image of agriculture and the barriers to enrolling in an agricultural education class. The population of the study consisted of 132 ninth grade students who were enrolled in selected counties that had a high enrollment of minority students in public schools in the state of Arkansas during the spring of 2003. Their results showed that many students still had a positive perception of agriculture regardless of whether they had enrolled in an agricultural education class. The students were also more likely to enroll in an agricultural class because they believed it would benefit them in life and prepare them for an agricultural career. One of their recommendations was to implement an agricultural course in middle school to allow the students to broaden their perceptions of agriculture.

Moore (2013) surveyed 95 secondary principals with agricultural education programs in their schools and secondary principals without agricultural education programs in their school. The results indicated that secondary principals with agricultural education in their schools have a significantly higher perception of such programs than do secondary principals without agricultural education at their schools. The researcher reported that this finding was most likely due to the exposure and familiarities of principals with agricultural education programs in their schools. He concluded that possessing prior work experience in the field of agriculture played a role in the Kentucky secondary principals having a slightly more positive perception of agricultural education compared to principals with no prior agriculture work experience.

Russell (2016) surveyed 110 high school students' perception of not being enrolled in a high school agricultural education program. The target population for the study were students enrolled at Central Kentucky High School during the 2013-2014 school year. Seventy-nine of the students agreed with the statement that "agriculture is not for all students." The researcher 
reported that most students felt like they did not belong in an agriculture course. She also reported that more students felt that agriculture would prepare them for their career, but more students indicated that agricultural classes would not prepare them for college.

Hodson (1998) conducted research that looked at determining the perception that the member of the 1997 Louisiana Legislature held of the Louisiana Cooperative Extension Service (LCES) and identified factors that affected the perceptions. The factors included in the study were: familiarity with LCES programs, perception of effectiveness, sources of LCES information, and participation in LCES programs. Out of the 144 legislators contacted, 109 (76\%) surveys were returned. The results showed that rural legislators were more familiar with LCES, were more likely to be exposed to LCES information sources, perceived LCES as effective, and participated more in LCES activities than urban legislators. There was little correlation that existed between the age of the legislators, their years of service in the legislature and familiarity, participation, perception and participation.

Cannizzaro's (2007) study was looking to determine the importance of the Cooperative Extension Service (CES) as perceived by members of the local governing bodies in Louisiana. The target population for the study were members of the county/parish level governing bodies in 2006. 104 members of the local governing bodies responded to the survey. The results of the study revealed that the local governing body members served mostly in rural districts and were most aware of 4-H than any other program or service offered by the LCES. The local governing body member who perceived the importance of LCES programs and services also saw the LCES as effectively meeting the needs of local residents. 


\section{Summary}

The literature review began by showing the growth and change of the agriculture industry and agricultural education curriculum over the past 100 years in the United States. All states in the union are eligible to receive federal funding for agricultural education but there a few states in the nation that have a separate agricultural education line item in their state budget. Some states have had their agricultural education funding cut. The existing literature has looked at the perception of agriculture and agricultural education from many views but has neglected to research the factors contributing to the state legislator's view on school-based agricultural education.

Some factors determined a person's attitude toward agriculture or agriculture education. Those variables included age, agriculture experience, occupation, and exposure to agricultural education. It is necessary to know these factors in order to determine the legislators' perception of school-based agricultural education. 


\section{CHAPTER III: METHODOLOGY}

The purpose of this study was to determine the factors contributing to the Illinois General Assembly members' perceptions on school-based agricultural education. This chapter described procedures used to conduct this research. Learning more about what factors contribute to a state legislator's attitudes and perceptions of school-based agricultural education will give advocates for school-based agricultural education a guide on how to effectively advocate for the programs. The process of creating instrumentation, participant recruitment, and procedures in this mixed methods research are provided in the following sections.

\section{Rationale}

This study utilized a mixed methods design. A mixed methods design is defined as "combining or integration of qualitative and quantitative research data in a research study" (Creswell, 2014, p. 14). Mixed methods were created because all methods have bias and weakness, but the collection of quantitative and qualitative data neutralizes the weakness of each form of data (Creswell, 2014).

Explanatory sequential mixed methods design was used in this study. Explanatory sequential mixed methods design consists of first conducting quantitative research, analyzing the results and then building those results to explain them in more detail with qualitative research (Creswell, 2014). This design is considered explanatory because the beginning quantitative data results are explained later with the qualitative data (Creswell, 2014). One of the challenges with this design is "identifying the quantitative results to further explore and the unequal sample sizes for each phase of the study" (Creswell, 2014, p. 15). Figure 2 demonstrates the explanatory sequential mixed methods design in a flow chart. 


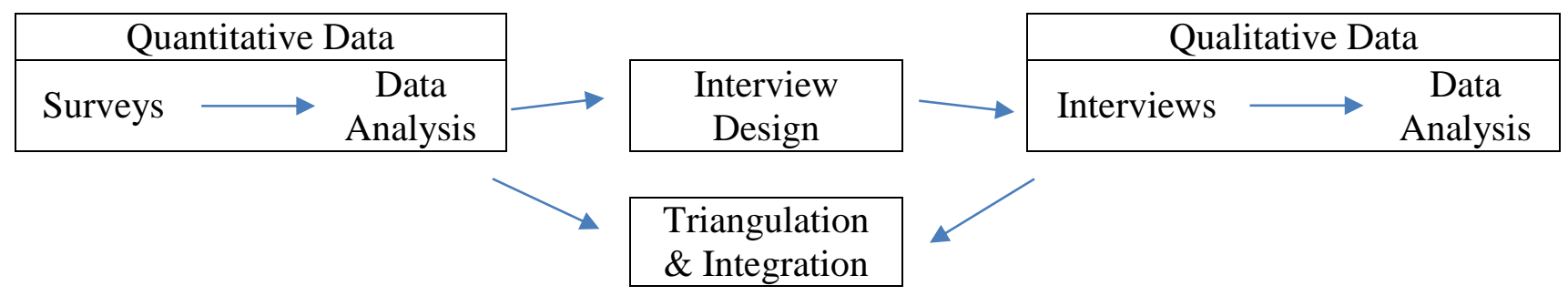

Figure 2: Explanatory Sequential Mixed Methods Design

\section{Participants}

The target population for this study was defined as members of $100^{\text {th }}$ Illinois General Assembly. These legislators served from 2016-2018. The researchers used total population sampling for this research. Total population sampling is a type of purposive sampling technique that involved examining the total population that has a particular set of characteristics ("Total Population Sampling," 2012). In the total population, there were 177 members that were contacted to participate in the research. The Pew Charitable Trusts and the National Conference of State Legislatures researched the demographics of each legislature in the United States (Gioia, Weberg, Ballou, Powell, \& Santos, 2015). These demographic data were collected and published in 2015. However, the age and gender of the state legislatures were updated in January 2016. We believe the data they collected are still an accurate representation of the state legislature in Illinois. Table 1 includes the demographic data obtained from this research compared to the demographic data published. All legislators who gave consent on the questionnaire to participate in the interview were contacted to provide more responses and adequate data.

\section{Instrumentation}

The instrument used to collect data in the study was a researcher-designed questionnaire consisting of four parts. Portions of this instrument were adapted from two previous studies 
Table 1

Participant's Characteristics Compared to NCSL Characteristics

\begin{tabular}{|c|c|c|c|}
\hline $\begin{array}{l}\text { Variable } \\
\text { name }\end{array}$ & Group & $\begin{array}{r}\text { Questionnaire } \\
\text { Response }\end{array}$ & NCSL \\
\hline $\begin{array}{l}\text { Average } \\
\text { Age }\end{array}$ & & 49.61 years & 52.5 years \\
\hline \multirow[t]{2}{*}{ Gender } & Male & $51.1 \%$ & $68.0 \%$ \\
\hline & Female & $48.3 \%$ & $32.0 \%$ \\
\hline \multirow[t]{4}{*}{ Education } & $<$ Bachelors & $6.8 \%$ & $8.0 \%$ \\
\hline & Bachelors & $34.5 \%$ & $38.0 \%$ \\
\hline & Advanced & $58.6 \%$ & $42.0 \%$ \\
\hline & Unknown & $0.0 \%$ & $11.0 \%$ \\
\hline \multirow[t]{6}{*}{$\begin{array}{l}\text { Race and } \\
\text { Ethnicity }\end{array}$} & $\begin{array}{l}\text { American Indian/Native } \\
\text { Alaskan }\end{array}$ & $0.0 \%$ & $0.0 \%$ \\
\hline & Asian/Pacific Islander & $0.0 \%$ & $0.0 \%$ \\
\hline & Black/African American & $10.4 \%$ & $18.0 \%$ \\
\hline & Hispanic/Latino & $0.0 \%$ & $7.0 \%$ \\
\hline & Multiple races & $3.4 \%$ & $1.0 \%$ \\
\hline & White & $86.2 \%$ & $75.0 \%$ \\
\hline \multirow[t]{9}{*}{ Occupation } & Agriculture & $6.9 \%$ & $4.0 \%$ \\
\hline & Attorney & $17.3 \%$ & $20.0 \%$ \\
\hline & Business & $20.6 \%$ & $20.0 \%$ \\
\hline & Education & $10.4 \%$ & $5.0 \%$ \\
\hline & Consultation/Nonprofit & $3.4 \%$ & $7.0 \%$ \\
\hline & Full-time Legislator & $17.2 \%$ & $36.0 \%$ \\
\hline & Retired & $6.9 \%$ & $1.0 \%$ \\
\hline & No Data & $6.9 \%$ & $1.0 \%$ \\
\hline & Other & $10.4 \%$ & $8.0 \%$ \\
\hline
\end{tabular}


conducted by Hodson (1998) and Cannizzaro (2007) with similar research purposes. The questionnaire was also developed in accordance with the IRB policies and was reviewed and approved by the Illinois State University Institutional Review Board. The researcher had written permission from the two authors to modify the questions from their respective instruments which can be found in Appendix E.

The questionnaire included 16 five-point Likert-style questions measuring the perceptions of agriculture and school-based agricultural education. To test the internal consistency of the instrument, a Cronbach score was used (Creswell, 2014). Creswell (2014) defines a 0.7 Cronbach score or greater as acceptable, with anything less being questionable. The Cronbach's $\alpha$ coefficient for the perception of agriculture section scored a 0.688 with seven questions factored into the score. The Cronbach's $\alpha$ coefficient for the perception of schoolbased agricultural education section scored a 0.809 with nine questions factored into the score.

The first section of the questionnaire included demographic questions including selfidentified gender, age, educational background, and primary occupation.

The second section of the questionnaire was designed to measure the legislator's perceptions concerning the agriculture industry in Illinois. Seven agriculture issues were listed, and respondents were asked to indicate their response on a five-point Likert-type scale. The response scale and corresponding values for this portion of the instrument included: 1 = "Strongly Disagree," 2 = "Disagree," 3 = "Neither Agree nor Disagree," 4 = "Agree," and 5 $=$ "Strongly Agree."

The third section of the questionnaire was designed to measure the legislator's perception concerning school-based agricultural education. The respondents were asked to indicate their perception by marking their level of agreement on a five-point Likert-type scale. The response 
scale and corresponding values for this portion of the instrument included: 1 = "Strongly

Disagree," 2 = "Disagree," 3 = "Neither Agree nor Disagree," 4 = "Agree," and 5 = "Strongly Agree."

The fourth section of the questionnaire was designed to measure how often the legislators had been exposed to information (e.g. television, radio, personal contact, printed materials, etc.) about school-based agricultural education in Illinois. Respondents were asked to indicate how often they had seen, heard, or received information about school-based agricultural education in Illinois by using a six-point anchor scale using the following assigned values: $1=$ "None at all," $2=$ "Rarely (1-2 times a year)," 3 = "Occasionally (3-5 times a year)," 4 = "Moderately (6-11 times a year)," 5 = "Monthly (12 or more times a year)," and 6 = "Does not apply to me."

Content validity of the instrument was established through a review panel of experts composed of two university faculty members with expertise in instrument design, one former legislator that served in the Illinois General Assembly, one lobbyist for an agricultural company and one researcher who is familiar with the agriculture industry but has limited knowledge on school-based agricultural education.

\section{Data Collection for Quantitative Questionnaire}

Illinois State University Institution Review Board (IRB) approval was obtained before data collection. The IRB letter for this study is included in Appendix A.

Data for this study were collected using the following steps:

1. Participants' official email addresses were obtained by visiting the Illinois General Assembly website. If their email address was not available, a phone call was made to the participant's office to obtain an email address. The cover letter along with the link to the questionnaire was emailed to every participant. 
2. Seven days after the initial email was sent, a follow-up email was sent out to all the participants. This email asked if the participants had received the first email and if they could complete the questionnaire are at their earliest convenience.

3. Fifteen days after the initial email was sent, a second follow up email was sent out to all the participants. This email asked the legislators to complete the questionnaire at their earliest convenience and encouraged the participants to ask their other colleagues to complete the questionnaire.

4. Twenty-eight days after the initial questionnaire was sent out, the researcher closed the questionnaire. After review, the researcher was concerned that the questionnaire response rate was very low. The researcher decided to send out an additional email extending the timeline of the questionnaire until after the Christmas holidays.

5. Forty-three days after the initial questionnaire was sent out, the researcher sent out an email to the participants explaining there was an extension of the submission deadline for the questionnaire.

6. Fifty-one days after the initial questionnaire was sent out, a thank you email was sent to all the respondents thanking them for participating in the questionnaire.

\section{Data Collection for Qualitative Interviews}

Data for this study were collected by the following:

1. An interview invitation was emailed to all the participants who indicated that they wanted to be interviewed for the interview section of the research. The emailed asked them to respond back with a date and time that worked best for their schedule.

2. The participants responded with a date and time that worked in their schedule and, the researcher confirmed the appointment with the participants. 
3. The researcher called the participant on the day and time they requested. The researcher typed their responses.

\section{Data Analysis}

The data from the study were evaluated using the procedures outlined below:

1. Is there a relationship between the demographics of the legislators on their perception of agriculture?

a. A Kruskal-Wallis $\mathrm{H}$ test was used to determine a significant difference between the demographic characteristics and their perception of agriculture.

2. Is there a relationship between the demographics of the legislators on their perception of school-based agricultural education?

a. A Kruskal-Wallis $\mathrm{H}$ test was used to determine a significant difference between the demographic characteristics and their perception of school-based agricultural education.

3. Is there a relationship between how often the legislators hear, see, or read something about school-based agricultural education on their perception of school-based agricultural education?

a. A Kruskal-Wallis $\mathrm{H}$ test was used to determine a significant difference between the different media sources and their perception of school-based agricultural education.

b. If the participant selected " $6=$ Does not apply to me" for information source score, that data were excluded from the analysis.

c. The source information was divided into three different sections: traditional media, social media, and other media. Traditional media included television, 
radio, and newspaper. Social media included Facebook, Instagram, and Twitter. Other media included personal contacts, contact from FFA alumni member, the Illinois Agricultural Education website, and invitations to school-based agricultural education activities.

4. Is there a relationship between the legislator's background experiences with farming on their perception of agriculture?

a. A Mann-Whitney U test was used to determine a significant difference between the legislator's experience farming and their perception of agriculture.

5. Is there a relationship between the legislator's background experiences with farming on their perception of school-based agricultural education?

a. A Mann-Whitney U test was used to determine a significant difference between the legislator's experience farming and their perception of school-based agricultural education.

\section{Quantitative Statistical Analysis}

Data were analyzed with IBM SPSS Statistics 24 using Kruskal-Wallis H one-way ANOVA on ranks test and Mann-Whitney U test. The small sample size for this set did not allow for the use of a multi-way analysis of variance. Significance was predetermined by $\mathrm{p}<$ 0.05. A Kruskal-Wallis $\mathrm{H}$ test is "a rank-based non-parametric test that can be used to determine if there are statistically significant differences between two or more groups of an independent variable on a continuous or ordinal scale" ("Kruskal-Wallis H Test using SPSS Statisitcs," n.d.). Similar to a Kruskal-Wallis H test, a Mann-Whitney U test is "used to compare differences between two independent groups when the dependent variable is either ordinal or continuous, but not normally distributed" ("Mann-Whitney U Test using SPSS Statistics," n.d.). 
The independent variables included the population area of where the legislator grew up, the population area of the district the legislator represents, the geographical location of the legislator's district, whether the legislator lived on a farm, and whether the legislator worked on a farm. The independent variables also included frequency of seeing information about schoolbased agricultural education on multiple media source including television, radio, newspaper, Facebook, Twitter, Instagram, constituents in school-based agricultural education programs, family and FFA alumni member, Illinois Agricultural Education website, and invitations to school-based agricultural education program events. The dependent variables used in the analysis were the scores of the legislators' perception of agriculture, the scores of the legislators' perception of school-based agricultural education, and the scores of the frequency of legislators seeing information about school-based agricultural education.

\section{Qualitative Data Analysis}

Research assistants at the University of Wisconsin-Extension outlined five steps how qualitative should be analyzed (Taylor-Powell \& Renner, 2003). This analytical process was used to interpret the interview responses.

The first step was to explore and understand the data. This step was accomplished by reading the interview responses three times before analyzing the data. Any first impressions about the responses were captured in research memos in the margins. The second step was to focus the analysis. This step was accomplished by organizing all the answers to each question, and the responses can be found in Appendix G.

The third step was to categorize the information. This step required finding themes or patterns and organized them into categories. This step was accomplished by reading each question's responses and determining if there were themes located in the responses. The 
researcher read over the question's response five times to find any themes. The fourth step was to identify patterns and connections within and between categories. The researcher noted if themes were brought up more than once and determined if there were any relationships between the themes. The fifth step included interpreting the data. The researcher used the themes and connection to explain the survey findings.

\section{Summary}

This chapter provided the methodology used in the study. The following chapter describes the results of the study and examines each of the hypotheses to determine the study findings. 


\section{CHAPTER IV: RESULTS}

The purpose of this study was to determine the factors contributing to the Illinois General Assembly member's perceptions on school-based agricultural education. This chapter described the results of the research questions by analyzing the quantitative and qualitative data. Learning more about what factors contribute to a state legislator's perceptions of school-based agricultural education will give advocates for school-based agricultural education a guide on how to effectively advocate for the programs.

Thirty respondents out of 177 legislators completed the questionnaire, but 29 of them were considered valid. The other response was not adequately filled out. This resulted in a $16.4 \%$ response rate. We did not address the nonresponse bias because it would have been impractical to collect to more data samples. One way to prevent nonresponse error is by comparing respondents to nonrespondents. Research standards suggest collecting 20 additional responses from a random sample of nonrespondents and comparing the responses to the original responses (Lindner, Murphy, \& Briers, 2001). This procedure would not be plausible as the researchers only collected 29 responses when the questionnaire was sent out.

The following research questions were posed:

1. Is there a relationship between the demographics of the legislators on their perception of agriculture?

2. Is there a relationship between the demographics of the legislators on their perception of school-based agricultural education?

3. Is there a relationship between how often the legislators hear, see, or read something about school-based agricultural education on their perception of school-based agricultural education? 
4. Is there a relationship between the legislator's background experiences with farming on their perception of agriculture?

5. Is there a relationship between the legislator's background experiences with farming on their perceptions of school-based agricultural education?

This chapter presents the findings for research questions 1-5.

\section{Research Question One}

Is there a relationship between the demographics of the legislators on their perception of agriculture?

A Kruskal-Wallis $\mathrm{H}$ test was utilized to address the first research question and the three hypotheses associated with the first research question.

\section{Null Hypothesis 1}

There is no significant difference in the legislators' perceptions of agriculture based on where they grew up.

A Kruskal-Wallis $\mathrm{H}$ test was conducted to evaluate differences among the five population areas (rural living on a farm, rural not living on a farm, town, suburban, and city) where the legislator grew up and the legislators' perception of agriculture. The test, which was corrected for tied ranks, was not significant $\chi^{2}(4, N=27)=5.963, p=.202$ (Table 2). Since this value produced a significant difference above $p>.05$, the researcher failed to reject the null hypothesis. As the research indicates, the population area where the legislator grew up did not affect the legislators' perception of agriculture. 
Table 2

Hypothesis 1 Results: Where the Legislator Grew Up and the Legislator's Perception of Agriculture

\begin{tabular}{|c|c|c|c|}
\hline & Population Area & $\mathrm{N}$ & Mean Rank \\
\hline \multirow[t]{6}{*}{ Perception of Agriculture } & $\begin{array}{l}\text { Rural living on a } \\
\text { farm }\end{array}$ & 3 & 22.33 \\
\hline & $\begin{array}{l}\text { Rural not living on a } \\
\text { farm }\end{array}$ & 4 & 14.13 \\
\hline & $\begin{array}{l}\text { Town ( } 1 \text { to } 9,999 \text { in } \\
\text { population size) }\end{array}$ & 5 & 14.60 \\
\hline & $\begin{array}{l}\text { Suburban }(10,000- \\
49,999 \text { in population } \\
\text { size }\end{array}$ & 8 & 9.63 \\
\hline & $\begin{array}{l}\text { City }(50,000 \text { and over } \\
\text { in population size })\end{array}$ & 7 & 14.93 \\
\hline & Total & 27 & \\
\hline
\end{tabular}

\section{Null Hypothesis 2}

There is no significant difference in the legislators' perceptions of agriculture based on the population area of the legislators' district.

A Kruskal-Wallis $\mathrm{H}$ test was conducted to evaluate differences among the five population areas (rural living on a farm, rural not living on a farm, town, suburban, and city) of the legislators' district and the legislators' perception of agriculture. The test, which was corrected for tied ranks, was not significant $\chi^{2}(4, N=28)=5.027, p=.285$ (Table 3 ). Since this value produced a significant difference above $p>.05$, the researcher failed to reject the null hypothesis. As the research indicates, the population area of the legislator's district did not affect the legislators' perception of agriculture.

\section{Null Hypothesis 3}

There is no significant difference in the legislators' perceptions of agriculture based on the geographical location of the legislators' district. 
A Kruskal-Wallis $\mathrm{H}$ test was conducted to evaluate differences among the four geographical location (Cook/Collar Counties, West of Illinois Route 47 and North of Interstate 80 , South of Interstate 80 and North of Interstate 70, and

Table 3

Hypothesis 2 Results: The Legislators' District and the Legislators' Perception of Agriculture

\begin{tabular}{|c|c|c|c|}
\hline Perception of Agriculture & Population Area & $\mathrm{N}$ & Mean Rank \\
\hline \multirow[t]{6}{*}{ Perception of Agriculture } & $\begin{array}{l}\text { Rural living on a } \\
\text { farm }\end{array}$ & 4 & 22.88 \\
\hline & $\begin{array}{l}\text { Rural not living on a } \\
\text { farm }\end{array}$ & 3 & 12.17 \\
\hline & $\begin{array}{l}\text { Town ( } 1 \text { to } 9,999 \text { in } \\
\text { population size) }\end{array}$ & 2 & 14.25 \\
\hline & $\begin{array}{l}\text { Suburban }(10,000- \\
49,999 \text { in population } \\
\text { size }\end{array}$ & 8 & 13.50 \\
\hline & $\begin{array}{l}\text { City }(50,000 \text { and over } \\
\text { in population size) }\end{array}$ & 11 & 12.86 \\
\hline & Total & 28 & \\
\hline Chi-Square value $=5.027$ & $\mathrm{df}=4$ & & \\
\hline
\end{tabular}

South of Interstate 70) of the legislator's district on their perception of agriculture. The test, which was corrected for tied ranks, was significant $\chi^{2}(3, N=28)=8.298, p=.040$ (Table 4). Since this value produced a significant difference below $p>.05$, the researcher rejected the null hypothesis. As the research indicates, the geographical locations of the legislators' district did affect the legislators' perception of agriculture.

Follow up tests were conducted to evaluate pairwise differences among the four groups, controlling for Type I error across tests by using the Bonferroni approach. The results of these tests indicated a significant difference between the Cook/Collar Counties group and the South of 80 and North of Interstate 70 group (Table 5). The legislators whose district is in the 
Cook/Collar Counties group tend to have a lower perception of agriculture compared to the legislators whose district is South of Interstate 80 and North of Interstate 70 group. There were no other significant differences among the other groups.

Table 4

Hypothesis 3 Results: Geographical Location of Legislators' District and Legislators ' Perception of Agriculture

\begin{tabular}{|c|c|c|c|}
\hline Perception of Agriculture & Geographical Area & $\mathrm{N}$ & Mean Rank \\
\hline \multirow[t]{5}{*}{ Perception of Agriculture } & $\begin{array}{l}\text { Cook/Collar Counties } \\
\text { (DuPage, Kane, Lake, } \\
\text { McHenry, and Will }\end{array}$ & 14 & 10.29 \\
\hline & $\begin{array}{l}\text { West of Illinois Route } \\
47 \text { and North of } \\
\text { Interstate } 80 \text { ) }\end{array}$ & 3 & 19.00 \\
\hline & $\begin{array}{l}\text { South of Interstate } 80 \\
\text { and North of } \\
\text { Interstate } 70\end{array}$ & 8 & 20.00 \\
\hline & South of Interstate 70 & 3 & 15.00 \\
\hline & Total & 28 & \\
\hline
\end{tabular}

Table 5

Pairwise Differences between Cook County/Collar Counties and South of Interstate 80 and North of Interstate 70 and Legislators' Perception of Agriculture

\begin{tabular}{|c|c|c|c|c|}
\hline & $\begin{array}{l}\text { Geographical } \\
\text { Area }\end{array}$ & $\mathrm{N}$ & Mean Rank & Sum of Ranks \\
\hline \multirow[t]{3}{*}{ Perception of Agriculture } & $\begin{array}{l}\text { Cook/Collar } \\
\text { Counties } \\
\text { (DuPage, Kane, } \\
\text { Lake, McHenry, } \\
\text { and Will }\end{array}$ & 14 & 8.82 & 123.50 \\
\hline & $\begin{array}{l}\text { South of Interstate } \\
80 \text { and North of } \\
\text { Interstate } 70\end{array}$ & 8 & 16.19 & 129.50 \\
\hline & Total & 22 & & \\
\hline Mann Whitney $U=18.500$ & $Z=-2.577$ & & $=.010$ & \\
\hline
\end{tabular}




\section{Research Question Two}

Is there a relationship between the demographics of the legislators on their perception of school-based agricultural education?

A Kruskal-Wallis $\mathrm{H}$ test was utilized to address the second research question and the three hypotheses associated with the second research question.

\section{Null Hypothesis 4}

There is no significant difference in the legislators' perceptions of school-based agricultural education based on where they grew up.

A Kruskal-Wallis $\mathrm{H}$ test was conducted to evaluate differences among the five population areas (rural living on a farm, rural not living on a farm, town, suburban, and city) where the legislators grew up and the legislators' perception of school-based agricultural education. The

test, which was corrected for tied ranks, was not significant $\chi^{2}(4, N=26)=4.824, p=.306$ (Table 6). Since this value produced a significant difference above $p>.05$, the researcher failed to reject the null hypothesis. As the research indicates, the population area of where the legislators grew up did not affect the legislators' perception of school-based agricultural education.

\section{Null Hypothesis 5}

There is no significant difference in the legislators' perceptions of school-based agricultural education based on population area of the legislators' district.

A Kruskal-Wallis $\mathrm{H}$ test was conducted to evaluate differences among the five population areas (rural living on a farm, rural not living on a farm, town, suburban, and city) of the legislators' district and the legislators' perception of school-based agricultural education. The test, which was corrected for tied ranks, was not significant $\chi^{2}(4, N=27)=4.187, p=.381$ 
(Table 7). Since this value produced a significant difference above $p>.05$, the researcher failed to reject the null hypothesis. As the research indicates, the population area of the legislators' district did not affect the legislators' perception of school-based agricultural education.

Table 6

Hypothesis 4 Results: Where the Legislators Grew Up and the Legislators' Perception of SchoolBased Agricultural Education

\begin{tabular}{llrr}
\hline & Population Area & N & Mean Rank \\
\hline $\begin{array}{l}\text { Perception of School- } \\
\text { Based Agricultural } \\
\text { Education }\end{array}$ & $\begin{array}{l}\text { Rural living on a } \\
\text { farm }\end{array}$ & 3 & 16.17 \\
& $\begin{array}{l}\text { Rural not living on a } \\
\text { farm } \\
\text { Town }(1 \text { to } 9,999 \text { in } \\
\text { population size })\end{array}$ & 5 & 15.00 \\
& $\begin{array}{l}\text { Suburban }(10,000- \\
49,999 \text { in population } \\
\text { size }\end{array}$ & 7 & 9.93 \\
& $\begin{array}{l}\text { City (50,000 and over } \\
\text { in population size })\end{array}$ & 7 & 11.43 \\
& Total & 26 & $\mathrm{p}=.306$
\end{tabular}

Null Hypothesis 6

There is no significant difference in the legislators' perceptions of school-based agricultural education based on the geographical location of the legislators' district.

A Kruskal-Wallis $\mathrm{H}$ test was conducted to evaluate differences among the four geographical location (Cook/Collar Counties, West of Illinois Route 47 and North of Interstate 80, South of Interstate 80 and North of Interstate 70, and South of Interstate 70) of the legislators' district and the legislators' perception of school-based agricultural education. The test, which was corrected for tied ranks, was significant $\chi^{2}(3, N=27)=10.515, p=.015$ (Table 
8). Since this value produced a significant difference below $p>.05$, the researcher rejected the null hypothesis. As the research indicates, the geographical locations of the legislators' district did affect the legislators' perception of school-based agricultural education.

Table 7

Hypothesis 5 Results: The Legislators' District and the Legislators' Perception of School-Based Agricultural Education

\begin{tabular}{|c|c|c|c|}
\hline & Population Area & $\mathrm{N}$ & Mean Rank \\
\hline \multirow{6}{*}{$\begin{array}{l}\text { Perception of School- } \\
\text { Based Agricultural } \\
\text { Education }\end{array}$} & $\begin{array}{l}\text { Rural living on a } \\
\text { farm }\end{array}$ & 4 & 18.63 \\
\hline & $\begin{array}{l}\text { Rural not living on a } \\
\text { farm }\end{array}$ & 3 & 17.83 \\
\hline & $\begin{array}{l}\text { Town ( } 1 \text { to } 9,999 \text { in } \\
\text { population size) }\end{array}$ & 2 & 18.75 \\
\hline & $\begin{array}{l}\text { Suburban }(10,000- \\
49,999 \text { in population } \\
\text { size }\end{array}$ & 7 & 11.79 \\
\hline & $\begin{array}{l}\text { City ( } 50,000 \text { and over } \\
\text { in population size) }\end{array}$ & 11 & 11.82 \\
\hline & Total & 27 & \\
\hline
\end{tabular}

Follow up tests were conducted to evaluate pairwise differences among the four groups, controlling for Type I error across tests by using the Bonferroni approach. The results of these tests indicated a significant difference between the Cook/Collar Counties group and the South of 80 and North of Interstate 70 group (Table 9). The legislators whose district is in the Cook/Collar Counties tend to have a lower perception of school-based agricultural education compared to the legislators whose district is South of Interstate 80 and North of Interstate 70.

The results also indicated a significant difference between the West of Illinois Route 47 and North of Interstate 80 group and South of Interstate 80 and North of Interstate 70 group 
(Table 10). The legislators whose district was located West of Illinois Route 47 and North of Interstate 80 had a lower perception of school-based agricultural education compared to the legislators whose district was located in South of Interstate 80 and North of Interstate 70. There were no other significant differences among the other groups.

Table 8

Hypothesis 6 Results: Geographical Location of Legislators' District and Legislators' Perception of School-Based Agricultural Education

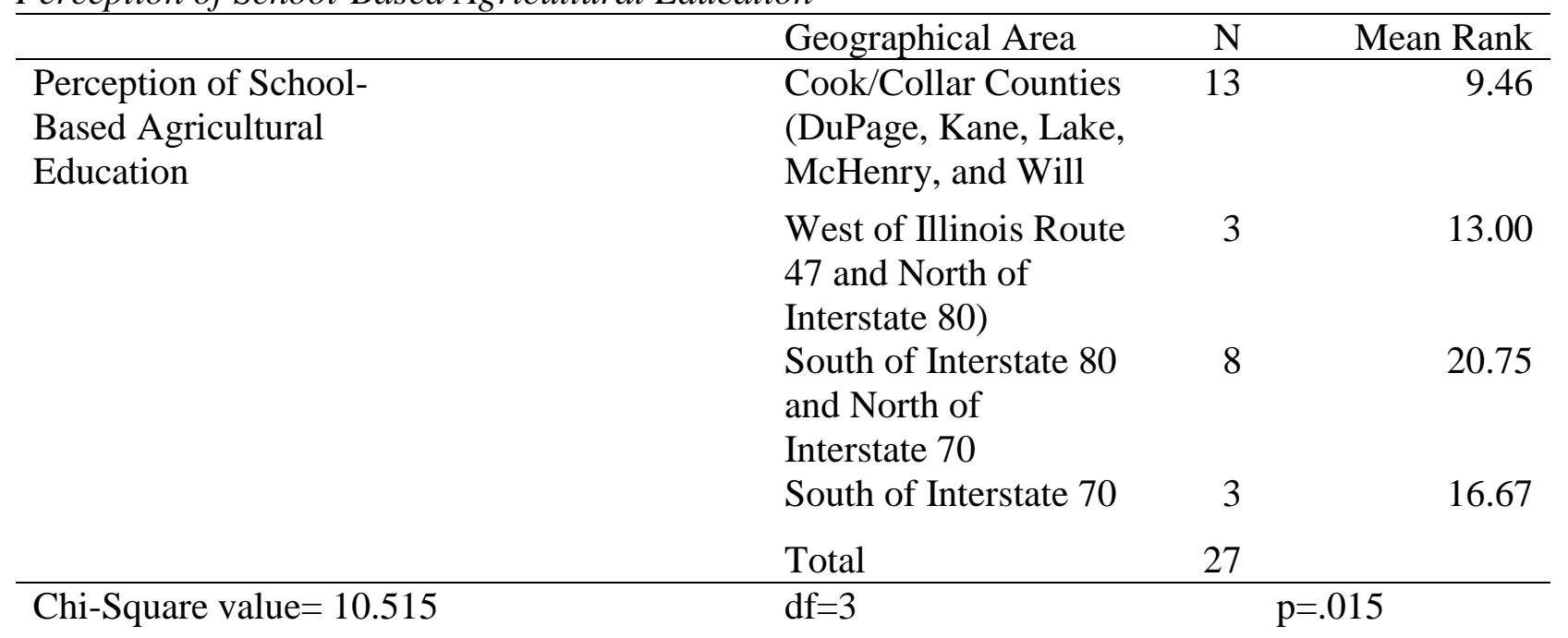

Table 9

Pairwise Differences between Cook County/Collar Counties group and South of Interstate 80 and North of Interstate 70 group and the Legislators' Perception of School-Based Agricultural Education

\begin{tabular}{llrrr}
\hline & Geographical Area & N & Mean Rank & Sum of Ranks \\
\hline Perception of School- & Cook/Collar & 13 & 8.04 & 104.50 \\
Based Agricultural & Counties (DuPage, & & & \\
Education & Kane, Lake, & & \\
& McHenry, and Will & & \\
& South of Interstate & 8 & 15.81 & 126.50 \\
& 80 and North of \\
Interstate 70 & & \\
Total & 21 & \\
& Z $=-2.797$ & \multicolumn{2}{c}{$\mathrm{p}=.005$} &
\end{tabular}


Table 10

Pairwise Differences between West of Illinois Route 47 and North of Interstate 80 group and South of Interstate 80 and North of Interstate 70 group and Legislators' Perceptions of SchoolBased Agricultural Education

\begin{tabular}{llrrr}
\hline & Geographical Area & $\mathrm{N}$ & Mean Rank & Sum of Ranks \\
\hline Perception of School- & West of Illinois & 3 & 2.50 & 7.50 \\
Based Agricultural & $\begin{array}{l}\text { Route 47 and North } \\
\text { of Interstate } 80\end{array}$ & & \\
Education & $\begin{array}{l}\text { South of Interstate } \\
80 \text { and North of } \\
\text { Interstate } 70\end{array}$ & & \\
& Total & & \\
& $\mathrm{Z}=-2.173$ & 21 & \\
& & \multicolumn{2}{c}{$\mathrm{p}=.030$} & \\
\hline Mann Whitney $\mathrm{U}=1.500$ & & &
\end{tabular}

\section{Research Question Three}

Is there a relationship between how often the legislators hear, see, or read something about school-based agricultural education on their perception of school-based agricultural education?

A Kruskal-Wallis $\mathrm{H}$ test was utilized to address the third research question and the ten hypotheses associated with the third research question.

\section{Null Hypothesis 7}

There is no significant difference in the legislators' perceptions of school-based agricultural education based on seeing information about school-based agricultural education on the television.

A Kruskal-Wallis $\mathrm{H}$ test was conducted to evaluate frequency differences (none at all, rarely, occasionally, moderately, and monthly) among legislators' perception of school-based agricultural education and how often they saw information about school-based agricultural education on the television. The test, which was corrected for tied ranks, was not significant $\chi^{2}(4, N=25)=4.576, p=.334$ (Table 11). Since this value produced a significant difference 
above $p>.05$, the researcher failed to reject the null hypothesis. As the research indicates, how often legislators saw information about school-based agricultural on the television did not affect their perception on school-based agricultural education.

Table 11

Hypothesis 7 Results: Seeing Information about School-Based Agricultural Education on the Television

\begin{tabular}{|c|c|c|c|}
\hline & Frequency & $\mathrm{N}$ & Mean Rank \\
\hline \multirow{6}{*}{$\begin{array}{l}\text { Perception of School- } \\
\text { Based Agricultural } \\
\text { Education }\end{array}$} & None at all & 9 & 9.67 \\
\hline & $\begin{array}{l}\text { Rarely (1-2 times a } \\
\text { year) }\end{array}$ & 9 & 13.33 \\
\hline & $\begin{array}{l}\text { Occasionally (3-5 } \\
\text { times a year) }\end{array}$ & 4 & 16.13 \\
\hline & $\begin{array}{l}\text { Moderately (6-11 } \\
\text { times a year) }\end{array}$ & 2 & 20.25 \\
\hline & $\begin{array}{l}\text { Monthly ( } 12 \text { or more } \\
\text { times a year) }\end{array}$ & 5 & 13.00 \\
\hline & Total & 27 & \\
\hline
\end{tabular}

\section{Null Hypothesis 8}

There is no significant difference in the legislators' perceptions of school-based agricultural education based on hearing information about school-based agricultural education on the radio.

A Kruskal-Wallis $\mathrm{H}$ test was conducted to evaluate frequency differences (none at all, rarely, occasionally, moderately, and monthly) among legislators' perception of school-based agricultural education and how often they heard information about school-based agricultural education on the radio. The test, which was corrected for tied ranks, was not significant $\chi^{2}(4, N$ $=26)=3.584, p=.465($ Table 12$)$. Since this value produced a significant difference above 
$p>.05$, the researcher failed to reject the null hypothesis. As the research indicates, how often legislators heard information about school-based agricultural on the radio did not affect their perception of school-based agricultural education.

Table 12

Hypothesis 8 Results: Hearing Information about School-based Agricultural Education on the Radio

\begin{tabular}{llrr}
\hline & Frequency & $\mathrm{N}$ & Mean Rank \\
\hline $\begin{array}{l}\text { Perception of School- } \\
\text { Based Agricultural } \\
\text { Education }\end{array}$ & None at all & 9 & 10.00 \\
& Rarely (1-2 times a & 8 & 16.81 \\
& $\begin{array}{l}\text { year) } \\
\text { Occasionally (3-5 } \\
\text { times a year) } \\
\text { Moderately (6-11 } \\
\text { times a year) } \\
\text { Monthly (12 or more } \\
\text { times a year) } \\
\text { Total }\end{array}$ & 7 & 13.79 \\
& df=4 & 1 & 16.50 \\
& 26 & 13.50 \\
\hline Chi-Square value $=3.584$ & \multicolumn{1}{c}{$\mathrm{p}=.465$}
\end{tabular}

\section{Null Hypothesis 9}

There is no significant difference in the legislators' perceptions of school-based agricultural education based on seeing information about school-based agricultural education in the newspaper.

A Kruskal-Wallis $\mathrm{H}$ test was conducted to evaluate frequency differences (none at all, rarely, occasionally, moderately, and monthly) among legislators' perception of school-based agricultural education and how often they saw information about school-based agricultural education in the newspaper. The test, which was corrected for tied ranks, was not significant $\chi^{2}(4, N=26)=3.261, p=.515$ (Table 13). Since this value produced a significant difference 
above $p>.05$, the researcher failed to reject the null hypothesis. As the research indicates, how often legislators saw information about school-based agricultural in the newspaper did not affect their perception of school-based agricultural education.

Table 13

Hypothesis 9 Results: Seeing Information about School-Based Agricultural Education in the Newspaper

\begin{tabular}{|c|c|c|c|}
\hline & Frequency & $\mathrm{N}$ & Mean Rank \\
\hline \multirow{6}{*}{$\begin{array}{l}\text { Perception of School- } \\
\text { Based Agricultural } \\
\text { Education }\end{array}$} & None at all & 9 & 10.17 \\
\hline & $\begin{array}{l}\text { Rarely (1-2 times a } \\
\text { year) }\end{array}$ & 3 & 18.33 \\
\hline & $\begin{array}{l}\text { Occasionally ( } 3-5 \\
\text { times a year) }\end{array}$ & 5 & 14.50 \\
\hline & $\begin{array}{l}\text { Moderately (6-11 } \\
\text { times a year) }\end{array}$ & 8 & 14.81 \\
\hline & $\begin{array}{l}\text { Monthly ( } 12 \text { or more } \\
\text { times a year) }\end{array}$ & 1 & 13.50 \\
\hline & Total & 26 & \\
\hline
\end{tabular}

\section{Null Hypothesis 10}

There is no significant difference in the legislators' perceptions of school-based agricultural education based on seeing information about school-based agricultural education on Facebook.

A Kruskal-Wallis $\mathrm{H}$ test was conducted to evaluate frequency differences (none at all, rarely, occasionally, moderately, and monthly) among legislators' perception of school-based agricultural education and how often they saw information about school-based agricultural education on Facebook. Two legislators indicated that they do not use Facebook, so their responses were not calculated in the analysis. The test, which was corrected for tied ranks, was 
significant $\chi^{2}(4, N=25)=11.470, p=.022$ (Table 14). Since this value produced a significant difference below $p>.05$, the researcher rejected the null hypothesis. As the research indicates, how often legislators saw information about school-based agricultural on Facebook did affect their perception of school-based agricultural education.

Table 14

Hypothesis 10 Results: Seeing Information about School-Based Agricultural Education on Facebook

\begin{tabular}{|c|c|c|c|}
\hline & Frequency & $\mathrm{N}$ & Mean Rank \\
\hline \multirow{6}{*}{$\begin{array}{l}\text { Perception of School- } \\
\text { Based Agricultural } \\
\text { Education }\end{array}$} & None at all & 10 & 8.15 \\
\hline & $\begin{array}{l}\text { Rarely (1-2 times a } \\
\text { year) }\end{array}$ & 3 & 22.83 \\
\hline & $\begin{array}{l}\text { Occasionally ( } 3-5 \\
\text { times a year) }\end{array}$ & 5 & 16.90 \\
\hline & $\begin{array}{l}\text { Moderately (6-11 } \\
\text { times a year) }\end{array}$ & 4 & 11.75 \\
\hline & $\begin{array}{l}\text { Monthly ( } 12 \text { or more } \\
\text { times a year) }\end{array}$ & 3 & 14.50 \\
\hline & Total & 25 & \\
\hline
\end{tabular}

Follow up tests were conducted to evaluate pairwise differences among the five groups, controlling for Type I error across tests by using the Bonferroni approach. The results of these tests indicated a significant difference between the "none at all" group and the "rarely" group (Table 15). The legislators who saw information about school-based agricultural education on Facebook at least one to two times a year had a higher perception of school-based agricultural education compared to legislators who did not see anything.

The results also indicated a significant difference between the "none at all" group and the “occasionally" group (Table 16). The legislators who saw information about school-based 
agricultural education on Facebook three to five times a year had a higher perception of schoolbased agricultural education compared to the legislators who did see anything on Facebook.

There were no other significant differences among the other groups.

Table 15

Pairwise Differences between Seeing Information about School-Based Agricultural Education "None at All" and "Rarely" on Facebook

\begin{tabular}{llrrr}
\hline & Frequency & $\mathrm{N}$ & Mean Rank & Sum of Ranks \\
\hline $\begin{array}{l}\text { Perception of School- } \\
\text { Based Agricultural }\end{array}$ & None at all & 10 & 5.55 & 55.50 \\
Education & & & \\
& Rarely (1-2 times a & 3 & 11.83 & 35.50 \\
& year) & & \\
& Total & 13 & \\
& $\mathrm{Z}=-2.461$ & \multicolumn{2}{c}{$\mathrm{p}=.014$}
\end{tabular}

Table 16

Pairwise Differences between Seeing Information about School-Based Agricultural Education "None at All" and "Occasionally" on Facebook

\begin{tabular}{llrrr}
\hline & Frequency & $\mathrm{N}$ & Mean Rank & Sum of Ranks \\
\hline $\begin{array}{l}\text { Perception of School- } \\
\text { Based Agricultural } \\
\text { Education }\end{array}$ & None at all & 10 & 6.25 & 62.50 \\
& & & \\
& $\begin{array}{l}\text { Occasionally }(3-5 \\
\text { times a year) } \\
\text { Total }\end{array}$ & 5 & 11.50 & 57.50 \\
& $\mathrm{Z}=-2.461$ & \multicolumn{2}{c}{$\mathrm{p}=.014$}
\end{tabular}




\section{Null Hypothesis 11}

There is no significant difference in the legislators' perceptions of school-based agricultural education based on seeing information about school-based agricultural education on Twitter.

A Kruskal-Wallis $\mathrm{H}$ test was conducted to evaluate frequency differences (none at all, rarely, occasionally, moderately, and monthly) among legislators' perception of school-based agricultural education and how often they saw information about school-based agricultural education on Twitter. Five legislators indicated that they do not use Twitter, so their responses were not calculated in the analysis. The test, which was corrected for tied ranks, was significant $\chi^{2}(4, N=21)=8.240, p=.041$ (Table 17). Since this value produced a significant difference below $p>.05$, the researcher rejected the null hypothesis. As the research indicates, how often legislators saw information about school-based agricultural on Twitter did affect their perception of school-based agricultural education.

Follow up tests were conducted to evaluate pairwise differences among the five groups, controlling for Type I error across tests by using the Bonferroni approach. The results of these tests indicated a significant difference between the "none at all" group and the "rarely" group (Table 18). The legislators who saw information about school-based agricultural education on Twitter at least one to two times a year had a higher perception of school-based agricultural education compared to legislators who did not see anything at all. There were no other significant differences among the other groups. 
Table 17

Hypothesis 11 Results: Seeing Information about School-Based Agricultural Education on Twitter

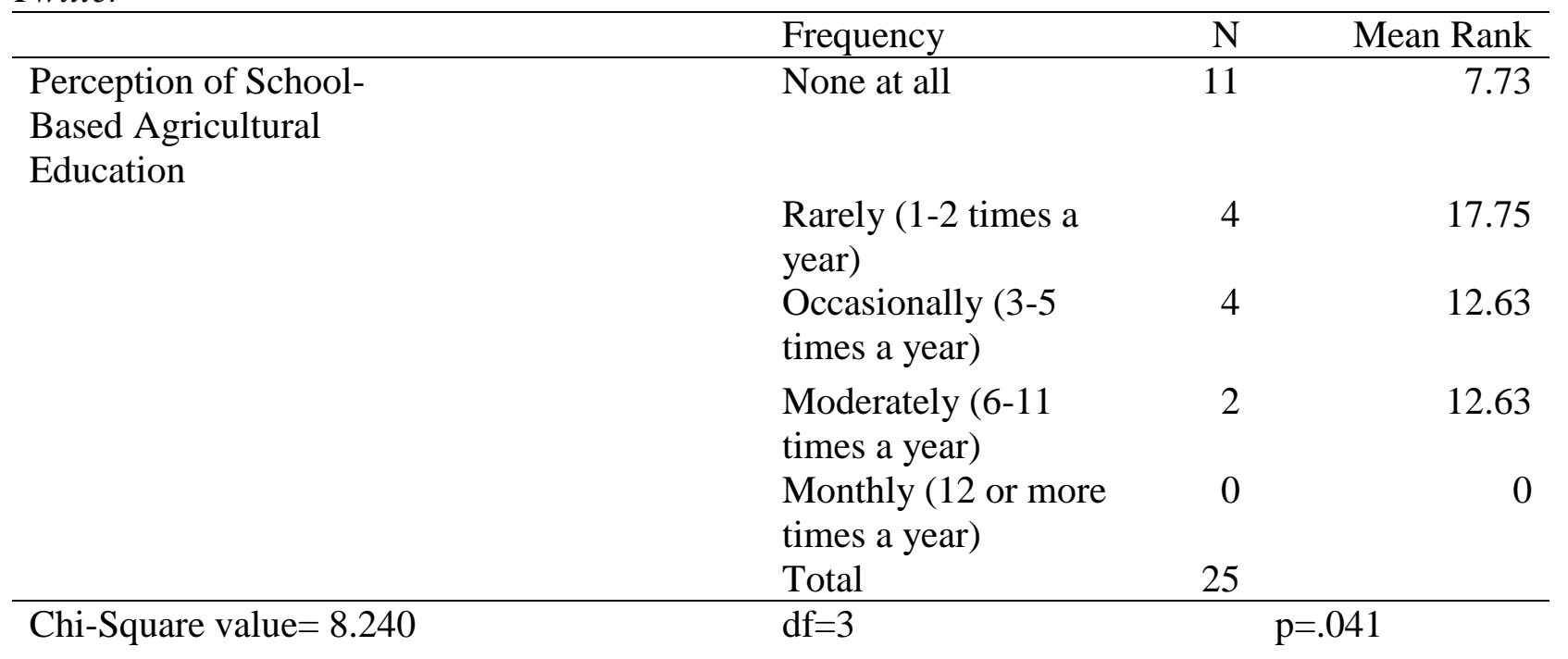

Table 18

Pairwise Differences between Seeing Information about School-Based Agricultural Education "None at All" and "Rarely" on Twitter

\begin{tabular}{|c|c|c|c|c|}
\hline & Frequency & $\mathrm{N}$ & Mean Rank & Sum of Ranks \\
\hline \multirow{3}{*}{$\begin{array}{l}\text { Perception of School- } \\
\text { Based Agricultural } \\
\text { Education }\end{array}$} & None at all & 11 & 6.36 & 70.00 \\
\hline & $\begin{array}{l}\text { Rarely (1-2 times a } \\
\text { year) }\end{array}$ & 4 & 12.50 & 50.00 \\
\hline & Total & 15 & & \\
\hline
\end{tabular}

Null Hypothesis 12

There is no significant difference in the legislators' perceptions of school-based agricultural education based on seeing information about school-based agricultural education on Instagram. 
A Kruskal-Wallis $\mathrm{H}$ test was conducted to evaluate frequency differences (none at all, rarely, occasionally, moderately, and monthly) among legislators' perception of school-based agricultural education and how often they saw information about school-based agricultural education on Instagram. Eight legislators indicated that they do not use Instagram, so their responses were not calculated in the analysis. The test, which was corrected for tied ranks, was not significant $\chi^{2}(4, N=21)=8.240, p=.140$ (Table 19$)$. Since this value produced a significant difference above $p>.05$, the researcher failed to reject the null hypothesis. As the research indicates, how often legislators saw information about school-based agricultural on Instagram did not affect their perception of school-based agricultural education.

Table 19

Hypothesis 12 Results: Seeing Information about School-Based Agricultural Education on Instagram

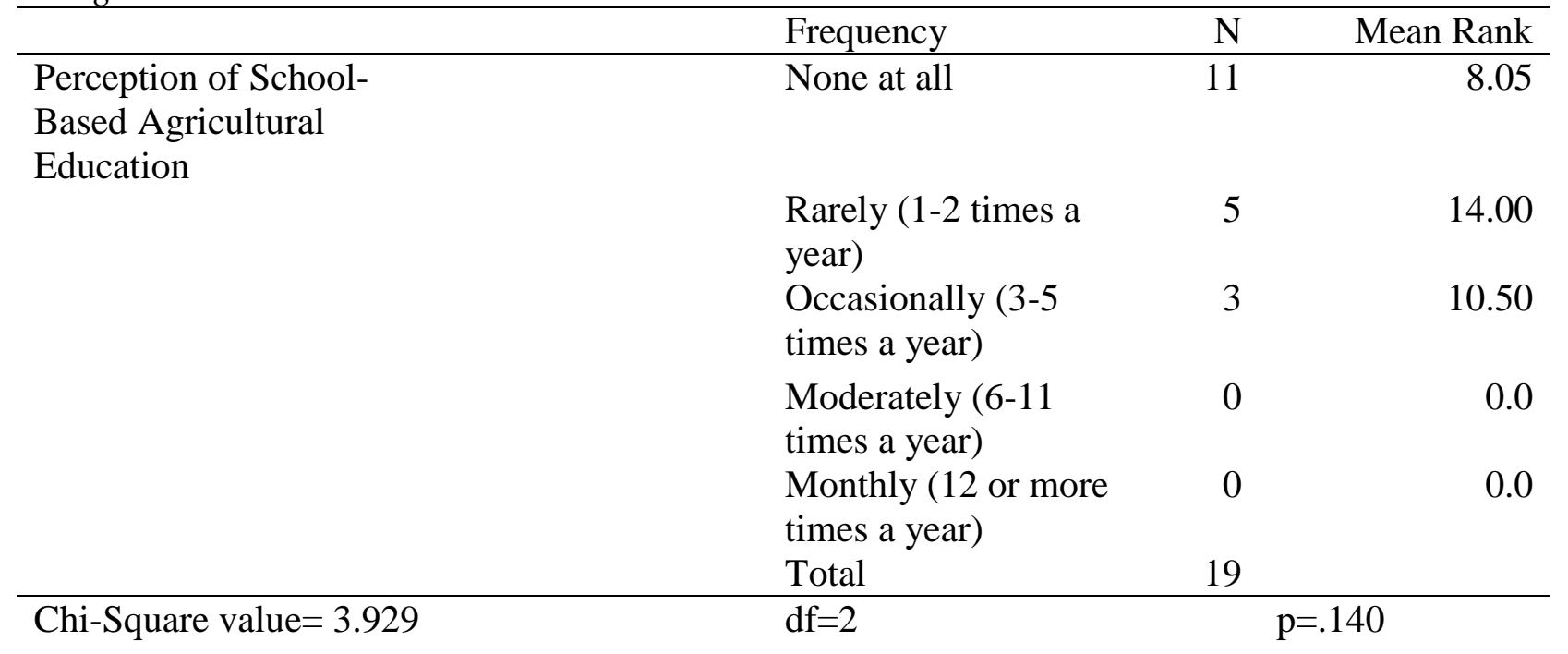




\section{Null Hypothesis 13}

There is no significant difference in the legislators' perceptions of school-based agricultural education based on receiving information from constituents in school-based agricultural education programs.

A Kruskal-Wallis $\mathrm{H}$ test was conducted to evaluate frequency differences (none at all, rarely, occasionally, moderately, and monthly) among legislators' perception of school-based agricultural education and how often they received information about school-based agricultural education from constituents in school-based agricultural education programs. Two legislators indicated that this does not apply to them, so their responses were not calculated in the analysis. The test, which was corrected for tied ranks, was not significant $\chi^{2}(4, N=24)=6.524, p=.163$ (Table 20). Since this value produced a significant difference above $p>.05$, the researcher failed to reject the null hypothesis. As the research indicates, how often legislators received information from constituents in school-based agricultural education programs did not affect their perception of school-based agricultural education.

\section{Null Hypothesis 14}

There is no significant difference in the legislators' perceptions of school-based agricultural education based on receiving information from family members and FFA alumni members about school-based agricultural education.

A Kruskal-Wallis $\mathrm{H}$ test was conducted to evaluate frequency differences (none at all, rarely, occasionally, moderately, and monthly) among legislators' perception of school-based agricultural education and how often they received information about school-based agricultural education from family members and FFA members involved in school-based agricultural education programs. One legislator indicated that this does not apply to them, so their response 
was not calculated in the analysis. The test, which was corrected for tied ranks, was not significant $\chi^{2}(4, N=25)=4.716, p=.318$ (Table 21$)$. Since this value produced a significant difference above $p>.05$, the researcher failed to reject the null hypothesis. As the research indicates, how often legislators received information from family members and FFA alumni members involved in school-based agricultural education programs did not affect their perception of school-based agricultural education.

Table 20

Hypothesis 13 Results: Receiving Information about School-Based Agricultural Education from Constituents in School-Based Agricultural Education Programs

\begin{tabular}{llrr}
\hline & Frequency & $\mathrm{N}$ & Mean Rank \\
\hline $\begin{array}{l}\text { Perception of School- } \\
\text { Based Agricultural } \\
\text { Education }\end{array}$ & None at all & 4 & 5.00 \\
& Rarely (1-2 times a & 8 & 12.88 \\
& $\begin{array}{l}\text { year) } \\
\text { Occasionally (3-5 } \\
\text { times a year) } \\
\text { Moderately (6-11 } \\
\text { times a year) } \\
\text { Monthly (12 or more } \\
\text { times a year) } \\
\text { Total }\end{array}$ & 4 & 14.50 \\
& df=4 & 4 & 12.75 \\
& & & 17.00 \\
\hline Chi-Square value $=6.524$ & \multicolumn{2}{c}{$\mathrm{p}=.163$}
\end{tabular}


Table 21

Hypothesis 14 Results: Receiving Information about School-Based Agricultural Education from Family Members and FFA Alumni Members involved in School-Based Agricultural Education Programs

\begin{tabular}{llrr}
\hline & Frequency & $\mathrm{N}$ & Mean Rank \\
\hline $\begin{array}{l}\text { Perception of School- } \\
\text { Based Agricultural } \\
\text { Education }\end{array}$ & None at all & 9 & 10.44 \\
& Rarely (1-2 times a & 6 & 11.08 \\
& $\begin{array}{l}\text { year) } \\
\text { Occasionally (3-5 } \\
\text { times a year) } \\
\text { Moderately (6-11 } \\
\text { times a year) } \\
\text { Monthly (12 or more } \\
\text { times a year) } \\
\text { Total }\end{array}$ & 3 & 13.63 \\
& df=4 & 3 & 18.17 \\
\hline Chi-Square value $=4.716$ & \multicolumn{2}{c}{$\mathrm{p}=.318$}
\end{tabular}

\section{Null Hypothesis 15}

There is no significant difference in the legislators' perceptions of school-based agricultural education based on receiving information from the Illinois Agricultural education website.

A Kruskal-Wallis H test was conducted to evaluate frequency differences (none at all, rarely, occasionally, moderately, and monthly) among legislators' perception of school-based agricultural education and how often they received information about school-based agricultural education from the Illinois Agricultural Education website. Two legislators indicated that this does not apply to them, so their responses were not calculated in the analysis. The test, which was corrected for tied ranks, was not significant $\chi^{2}(4, N=24)=9.355, p=.053$ (Table 22). Since this value produced a significant difference above $p>.05$, the researcher failed to reject the null hypothesis. As the research indicates, how often legislators received information from the 
Illinois Agricultural Education website did not affect their perception of school-based agricultural education.

Table 22

Hypothesis 15 Results: Receiving Information about School-Based Agricultural Education from the Illinois Agricultural Education Website

\begin{tabular}{llrr}
\hline & Frequency & $\mathrm{N}$ & Mean Rank \\
\hline $\begin{array}{l}\text { Perception of School- } \\
\text { Based Agricultural } \\
\text { Education }\end{array}$ & None at all & 15 & 9.23 \\
& Rarely (1-2 times a & 4 & 18.25 \\
& $\begin{array}{l}\text { year) } \\
\text { Occasionally (3-5 } \\
\text { times a year) } \\
\text { Moderately (6-11 } \\
\text { times a year) } \\
\text { Monthly (12 or more } \\
\text { times a year) } \\
\text { Total }\end{array}$ & 3 & 16.33 \\
& df=4 & 24 & 23.00 \\
\hline Chi-Square value $=9.355$ & \multicolumn{1}{c}{$\mathrm{p}=.053$}
\end{tabular}

\section{Null Hypothesis 16}

There is no significant difference in the legislators' perceptions of school-based agricultural education based on receiving invitations to school-based agricultural education activities.

A Kruskal-Wallis H test was conducted to evaluate frequency differences (none at all, rarely, occasionally, moderately, and monthly) among legislators' perception of school-based agricultural education and how often they received invitations to school-based agricultural education activities. One legislator indicated that this does not apply to them, so their response was not calculated in the analysis. The test, which was corrected for tied ranks, was significant $\chi^{2}(4, N=25)=10.250, p=.036($ Table 23$)$. 
Since this value produced a significant difference below $p>.05$, the researcher rejected the null hypothesis. As the research indicates, how often legislators received invitations to school-based agricultural education activities did affect their perception of school-based agricultural education.

Table 23

Hypothesis 16 Results: Receiving Invitations to School-Based Agricultural Education Activities

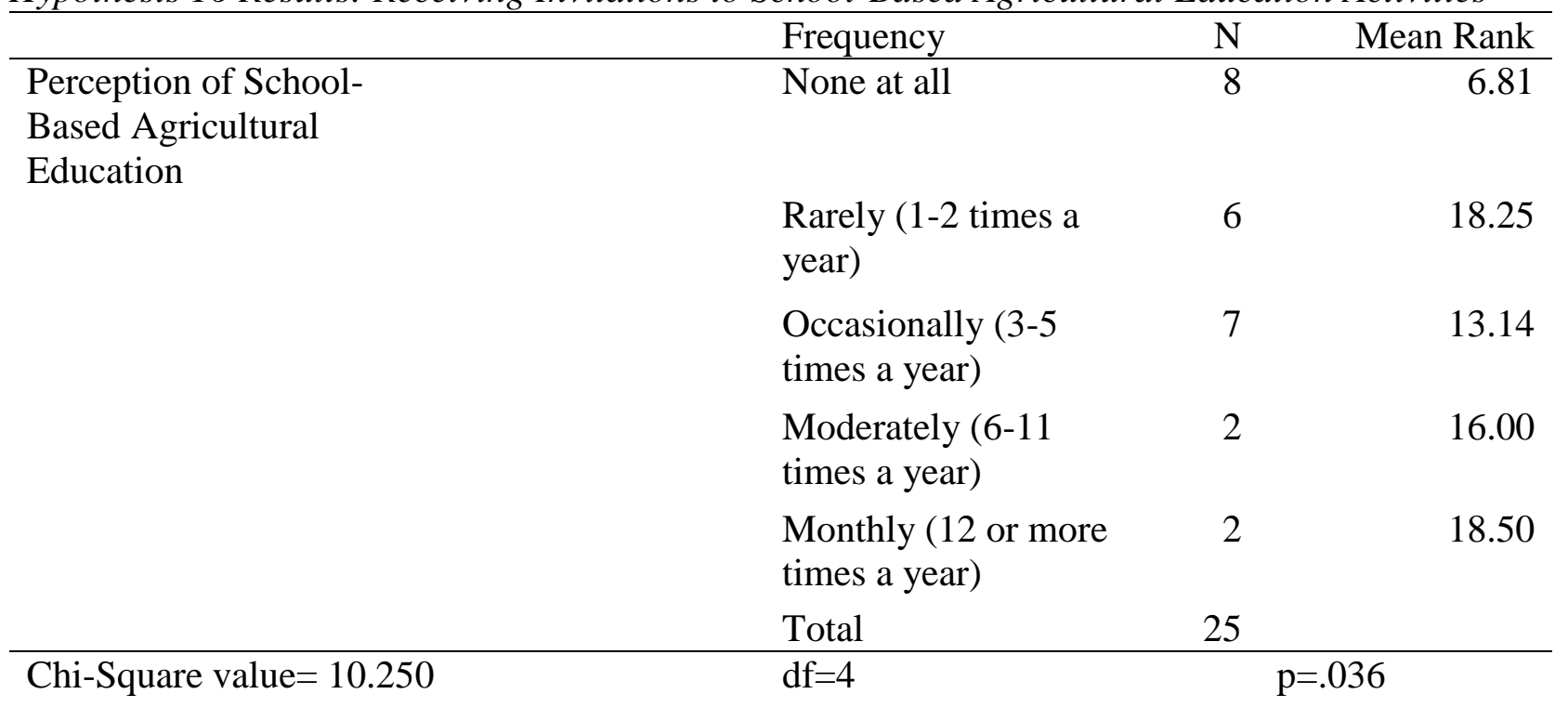

Follow up tests were conducted to evaluate pairwise differences among the five groups, controlling for Type I error across tests by using the Bonferroni approach. The results of these tests indicated a significant difference between the "none at all" group and the "rarely" group (Table 24). The legislators who received invitations to school-based agricultural education activities at least one to two times a year had a higher perception of school-based agricultural education compared to legislators who did not receive anything.

The results also indicated a significant difference between the "none at all" group and the "occasionally" group (Table 25). The legislators who received invitation to school-based 
agricultural education activities at least 3-5 years had a higher perception of school-based agriculture compared to the legislators who did not receive anything. There were no other significant differences among the other groups.

Table 24

Pairwise Differences between Receiving Invitations to School-Based Agricultural Education Events "None at All" and "Rarely"

\begin{tabular}{llrrr}
\hline & Frequency & N & Mean Rank & Sum of Ranks \\
\hline $\begin{array}{l}\text { Perception of School- } \\
\text { Based Agricultural } \\
\text { Education }\end{array}$ & None at all & 8 & 5.31 & 42.50 \\
& & & \\
& $\begin{array}{l}\text { Rarely (1-2 times a } \\
\text { year) }\end{array}$ & 6 & 10.42 & 62.50 \\
& Total & 14 & \\
\hline Mann Whitney U=6.500 & $\mathrm{Z}=-2.274$ & \multicolumn{2}{c}{$\mathrm{p}=.023$}
\end{tabular}

Table 25

Pairwise Differences between Receiving Invitations to School-Based Agricultural Education Events "None at All" and "Occasionally"

\begin{tabular}{llrrr}
\hline & Frequency & N & Mean Rank & Sum of Ranks \\
\hline $\begin{array}{l}\text { Perception of School- } \\
\text { Based Agricultural } \\
\text { Education }\end{array}$ & None at all & 8 & 5.63 & 45.00 \\
& & & \\
& $\begin{array}{l}\text { Occasionally (3-5 } \\
\text { times a year) } \\
\text { Total }\end{array}$ & 7 & 10.71 & 75.00 \\
& $\mathrm{Z}=-2.223$ & \multicolumn{2}{c}{$\mathrm{p}=.026$}
\end{tabular}

\section{Research Question Four}

Is there a relationship between the legislator's background experiences with farming on their perception of agriculture? 
A Mann-Whitney U test was utilized to address the fourth research question and the two hypotheses associated with the fourth research question.

\section{Null Hypothesis 17}

There is no significant difference in the legislators' perceptions of agriculture based on whether the legislator lived on farm.

A Mann-Whitney U test was conducted to determine (yes or no) living on a farm affected their perception of agriculture. Results of the analysis indicated that there was not a difference, $\underline{\mathrm{z}}$ $=-1.578, p=.114$ (Table 26). Since this value produced a significant difference above $p>.05$, the researcher failed to reject the null hypothesis. As the research indicates, if legislators lived on a farm did not affect their perception of agriculture.

Table 26

Hypothesis 17 Results: Lived on a Farm to their Perception of Agriculture

\begin{tabular}{llrrr} 
& Lived on a Farm? & N & Mean Rank & Sum of Ranks \\
\hline Perception of Agriculture & Yes & 7 & 18.71 & 131.00 \\
& No & 21 & 13.10 & 275.00 \\
& Total & & & \\
& Z $=-1.578$ & 28 & \\
\hline Mann Whitney U $=44.000$ & \multicolumn{2}{c}{$\mathrm{p}=.114$}
\end{tabular}

Null Hypothesis 18

There is no significant difference in the legislators' perceptions of agriculture based on whether the legislator worked on a farm.

A Mann-Whitney U test was conducted to determine (yes or no) working on a farm affected their perception of agriculture. Results of the analysis indicated that there was not a difference, $\underline{\mathrm{z}}=-1.258, p=.208$ (Table 27). Since this value produced a significant difference 
above $p>.05$, the researcher failed to reject the null hypothesis. As the research indicates, if legislators worked on a farm did not affect their perception of agriculture.

\section{Table 27}

Hypothesis 18 Results: Worked on a Farm to their Perception of Agriculture

\begin{tabular}{llrrr}
\hline & Worked on a Farm? & N & Mean Rank & Sum of Ranks \\
\hline Perception of Agriculture & Yes & 4 & 19.25 & 77.00 \\
& No & 24 & 13.71 & 329.00 \\
& Total & 28 & & \\
\hline Mann Whitney U=29.00 & Z $=-1.258$ & \multicolumn{2}{c}{$\mathrm{p}=.208$}
\end{tabular}

\section{Research Question Five}

Is there a relationship between the legislator's background experiences with farming on their perception of school-based agricultural education?

A Mann-Whitney U test was utilized to address the fifth research question and the two hypotheses associated with the fifth research question.

\section{Null Hypothesis 19}

There is no significant difference in the legislators' perceptions of school-based agricultural education based on whether the legislator lived on a farm.

A Mann-Whitney U test was conducted to determine (yes or no) living on a farm affected on their perception of school-based agricultural education. Results of the analysis indicated that there was not a difference, $\underline{z}=-1.195, p=.232$ (Table 28). Since this value produced a significant difference above $p>.05$, the researcher failed to reject the null hypothesis. As the research 
indicates, if legislators lived on a farm did not affect their perception of school-based agricultural education.

Table 28

Hypothesis 19 Results: Lived on a Farm to their Perception of School-Based Agricultural Education

\begin{tabular}{llrrr}
\hline & Lived on a Farm? & N & Mean Rank & Sum of Ranks \\
\hline $\begin{array}{l}\text { Perception of School- } \\
\text { Based Agricultural } \\
\text { Education }\end{array}$ & Yes & 7 & 17.07 & 119.50 \\
& No & 20 & 12.93 & 258.50 \\
& Total & 28 & \\
& $\mathrm{Z}=-1.195$ & \multicolumn{2}{c}{$\mathrm{p}=.232$}
\end{tabular}

Null Hypothesis 20

There is no significant difference in the legislators' perception of school-based agricultural education based on whether the legislator worked on a farm.

A Mann-Whitney U test was conducted to determine (yes or no) working on a farm affected their perception of school-based agricultural education. Results of the analysis indicated that there was not a difference, $\underline{\mathrm{z}}=-0.240, p=.810$ (Table 29). Since this value produced a significant difference above $p>.05$, the researcher failed to reject the null hypothesis. As the research indicates, if legislators worked on a farm did not affect their perception of school-based agricultural education. 
Table 29

Hypothesis 20 Results: Worked on a Farm to their Perception of School-Based Agricultural Education

\begin{tabular}{llrrr}
\hline & Worked on a Farm? & N & Mean Rank & Sum of Ranks \\
\hline $\begin{array}{l}\text { Perception of School- } \\
\begin{array}{l}\text { Based Agricultural } \\
\text { Education }\end{array}\end{array}$ & Yes & 4 & 14.88 & 59.50 \\
& No & 23 & 13.85 & 318.50 \\
& Total & 27 & \\
& $\mathrm{Z}=-0.240$ & \multicolumn{2}{c}{$\mathrm{p}=.810$}
\end{tabular}

\section{Qualitative Interview Questions}

The second and final data collection was the phone interviews conducted with four participants. The conversation during the interviews was transcribed and then analyzed finding themes and connections. The analyzed data resulted in four themes, statements from each theme can be found in Table 30, and the results are also discussed in detail below. See Appendix G for all the responses from the participants.

\section{Agriculture is Food Production}

The participants expressed that food production is directly tied to their interpretation of agriculture. During the interview, each of the participants referred to food as agriculture at least one time. When asked how agriculture impacts their life, Participant One said: “...local farms provide access to food." Participant Two stated, "Our family discussed growing food in local communities."

Participants also expressed there are different ways that agriculture is connected to the food production. Participant Four stated that agriculture impacted their life "by all of the food I eat." Participant Two articulated that "agriculture is connected to food insecurity." On the other 
Table 30

Statements of Each Theme of Focus Groups

\begin{tabular}{ll}
\hline Theme & \multicolumn{1}{c}{ Statements } \\
\hline "I remember agriculture as food and the smell of \\
the onion field by our house." \\
"Our family discussed growing food in local \\
communities." \\
"Obviously from a nonfarm perspective, local \\
farms provide access to food." \\
"I feel that agriculture is connected to food \\
insecurity. Agriculture is something that we are \\
looking towards to have been food access and \\
have it be more economical for people living in \\
the city they can afford." \\
"We have some farmers markets and farmers who \\
sell their products that are locally grown. \\
Agriculture would impact me by general food \\
consumption." \\
"By all of the food I eat. Agriculture is huge!"
\end{tabular}

\begin{tabular}{ll} 
Agriculture is not an urban issue & $\begin{array}{l}\text { "We did not talk about agriculture in our home } \\
\text { growing up. We grew up in the suburbs and } \\
\text { didn't talk about it that much." } \\
\text { "It (agriculture) wasn't a normal conversation } \\
\text { because we were from the inner city of Chicago. } \\
\text { It was not talked about." }\end{array}$ \\
\hline Farm economy was shaky & $\begin{array}{l}\text { "There were a lot of farms being sold to } \\
\text { development, but there were complaints coming } \\
\text { from the suburban area about the smell of onion." } \\
\text { (table continues) }\end{array}$
\end{tabular}




\begin{tabular}{ll}
\hline Theme & \multicolumn{1}{c}{ Statements } \\
\hline "Our family drove by farms all of the time and, I \\
remember being exposed to them but now they \\
are just shopping malls. But there was a quite a \\
bit of farms." \\
"It was not the greatest for farmers. During that \\
time period, there were a lot of concerns. Many \\
people were losing their farms. I remember that \\
there was rock concerts happening to help support \\
the farmers. It was not a strong industry at the \\
time."
\end{tabular}

hand, Participant Three said, “...farmers who sell their products that are locally grown.”

Urban Agriculture is Gardening

Participants expressed that urban agriculture is focused on gardening and learning how to most efficiently utilize the small growing spaces. Participant Two expressed that their family gardened a fair amount growing up in the inner city of Chicago. Participant Three stated that gardening in urban areas is learning "how to grow food in maximum number of volume in a small space."

\section{Agriculture is Not an Urban Issue}

The participants discussed why agriculture is not an urban issue. Participant Three stated "We did not talk about agriculture in our home growing up. We grew up in the suburbs and didn't talk about it that much." Participant Two expressed a very similar statement. They stated “We didn't talk about them (agriculture topics) per se. It wasn't a normal conversation because we were from the inner city of Chicago. It was not talked about."

\section{Farm Economy was Shaky}

Participants were asked to recall what the farming economy was like when they were growing up. Three of the participants stated concerns that farms were being sold to development 
or the farmers were losing their farm to the unstable farm economy. Participant One said, "There were a lot of farms being sold to development, but there were complaints coming from the suburban area about the smell of the onions." Participant Four stated concerns about "Many people were losing their farm. It was not a strong industry at the time."

\section{Summary}

This chapter presented data from a quantitative instrument measuring a legislator's perception of agriculture, the perception of school-based agricultural education, and indicating how many times they heard or saw information about school-based agricultural education throughout the year. This chapter also looked at the themes resulting from phone interviews that were conducted after quantitative data had been analyzed. 


\section{CHAPTER V: DISCUSSION \& RECOMMENDATIONS}

The purpose of this study was to determine the factors contributing to the Illinois General Assembly members' attitudes on school-based agricultural education. This chapter describes the discussion and recommendations of the research questions by analyzing the quantitative and qualitative data. These two data sets were used to help triangulate results. Learning more about what factors contribute to a state legislator's attitudes and perceptions of school-based agricultural education will give advocates for school-based agricultural education a guide on how to effectively advocate for the programs.

\section{Discussion}

Based on the findings of this study, research question one through five can be addressed by primarily interpreting the data of the first instrument. In addition, statements from the phone interviews can be used to help triangulate results.

\section{Research Question 1}

The first research question for the study was: Is there a relationship between the demographics of the legislators on their perception of agriculture? The null hypotheses with research question one was: (1) there is no significant difference in the legislators' perceptions of agriculture based on where they grew up, (2) there is no significant difference in the legislators' perceptions of agriculture based on the population area of the legislators' district, and (3) there is no significant difference in the legislators' perceptions of agriculture based on the geographical location of the legislators' district.

The data suggested that there were significant differences between the geographical location of the legislator's district and their perception of agriculture. No significant differences were found between the other two factors and their perception of agriculture. The researcher did 
not anticipate the results for null hypotheses one and two. The literature discussed background, interest, and experience can play a role in their perception.

For this study, the researcher found a significant difference between the legislators whose district is in Cook/Collar Counties group and South of Interstate 80 and North of Interstate 70 group to their perception of agriculture. The researcher found legislators whose district was in Cook/Collar Counties had a lower perception of agriculture. The legislators who are in the South of Interstate 80 and North of Interstate 70 group may have a higher perception of agriculture because that area is Illinois has a lot of farmland. The qualitative data also created the same conclusions as the quantitative data. The legislators who grew up in the urban areas tended to think of agriculture as gardening. If a legislator thinks of agriculture as gardening, then they probably will not look at agriculture as an industry like business, computers, and education. Being around production agriculture may be a factor that contributes to a higher perception of agriculture. These results are consistent with the previous finding that school principals with school-based agricultural education programs have a higher perception of them perhaps due to the familiarity with the programs. Advocates for agriculture should be conscious of this finding when talking to legislators in urban areas about agriculture issues. They should also employ effective marketing strategies when discussing agriculture policies with the legislators and explain how these policies could impact their district and Illinois.

\section{Research Question 2}

The second research question for the study was: Is there a relationship between the demographics of the legislator on their perception of school-based agricultural education? The three null hypotheses associated with research question number two are: (4) there is no significant difference in the legislators' perceptions of school-based agricultural education based 
on where they grew up, (5) there is no significant difference in the legislators' perceptions of school-based agricultural education based on population area of the legislators' district, and (6) there is no significant difference in the legislators' perceptions of school-based agricultural education based on the geographical location of the legislators' district. Like the perception of agriculture, the data suggested that there were significant differences between the geographical location of the legislators' district and their perception of school-based agricultural education. However, there were no significant differences between the other two factors and the legislators' perception of school-based agricultural education.

The results from research question two were anticipated by the researcher. Null hypothesis six reports three of the groups are significantly different from each other. The South of Interstate 80 and North of Interstate 70 group had a higher perception score of school-based agricultural education compared to the other two groups. There are many school-based agricultural education programs located in Central and South-Central Illinois, and the relatively high population of programs may contribute to their perception.

These results also indicate that legislators whose district is in the Cook/collar counties group have a lower perception of school-based agricultural education. There are a lot less school-based programs located in the Cook/Collar Counties group compared to the other three groups. The legislators' lack of exposure to school-based agriculture education programs contributes to their perception of the programs. It should be alarming that legislators in the Cook/Collar Counties group have a lower perception of school-based agricultural education because a large percentage of the state legislature is from that section of Illinois. In Illinois, the state legislature allocates funding specifically for school-based agricultural education. If the 
legislators are not aware of what the funding accomplishes, there is a likelihood of the line item getting cut from future budgets.

Qualitative data also indicated that the legislators are not aware of what classes are taught in urban and rural school-based agricultural education programs. They believed that urban school-based agricultural education programs focus more on gardening while rural programs are focused on production agriculture practices like managing different livestock operations and utilizing different soil programs.

\section{Research Question 3}

The third research question for the study was: Is there a relationship between how often the legislators hear, see, or read something about school-based agricultural education on their perception of school-based agricultural education? The null hypotheses with research question three were: (7) there is no significant difference in the legislators' perceptions of school-based agricultural education based on seeing information about school-based agricultural education on the television, (8) there is no significant difference in the legislators' perceptions of school-based agricultural education based on hearing information about school-based agricultural education on the radio, (9) there is no significant difference in the legislators' perceptions of school-based agricultural education based on seeing information about school-based agricultural education in the newspaper, (10) there is no significant difference in the legislators' perceptions of schoolbased agricultural education based on seeing information about school-based agricultural education on Facebook, (11) there is no significant difference in the legislators' perceptions of school-based agricultural education based on seeing information about school-based agricultural education on Twitter, (12) there is no significant difference in the legislators' perceptions of school-based agricultural education based on seeing information about school-based agricultural 
education on Instagram, (13) there is no significant difference in the legislators' perceptions of school-based agricultural education based on receiving information from constituents in schoolbased agricultural education programs, (14) there is no significant difference in the legislators' perceptions of school-based agricultural education based on receiving information from family members and FFA alumni members about school-based agricultural education, (15) there is no significant difference in the legislators' perceptions of school-based agricultural education based on receiving information from the Illinois Agricultural education website, and (16) there is no significant difference in the legislators' perceptions of school-based agricultural education based on receiving invitations to school-based agricultural education activities. No significant differences were existing in null hypotheses $7,8,9,12,13,14$, and 15 . However significant differences were existing in 10, 11, and 16.

The researcher was anticipating the results of null hypothesis 10 and 11. In the era of "fake news," it is difficult to know which news source is real and which is fake and that can have a huge impact on someone's perception. The Pew Research just completed on a 13-year study on the growth of representation on social media. In January 2018 report, at least $61 \%$ of adults use at least one social media site ("Social Media Fact Sheet," 2018). The same report concluded that at least $64 \%$ of people from the age of 50 to 64 use at least one social media site and $68 \%$ of U.S. adults use Facebook. The average age of the participant in this study was almost 50 years old so they fall into the category listed above.

These results indicate that school-based agricultural education programs need to share on Facebook at least three to five times a year to influence a legislator's perception of school-based agricultural education. Some events to share on social media would include the results of a career development event, the upcoming chapter banquet, or the chapter's fundraiser. It is not 
necessary to over post information about school-based agricultural education on social media because it would not have a significant difference on the legislator's perception of school-based agricultural education.

The researcher was not anticipating the results of null hypothesis 16. As stated earlier, at least $61 \%$ of adults in the United States have one type of social media website. Even though society is living in a digital age, some generations still prefer to receive hard copies of letters and cards. The average age of the legislators falls in the category of Generation X. Michael Fleischner (2006) reported than $86 \%$ of Generation Xers bring in the mail the day it's delivered. Generation $\mathrm{X}$ consumers rate $75 \%$ of the mail they receive as valuable. From the research, this is still important to send paper copies to Generation Xers. When legislators did receive invitations to school-based agricultural education activities, it did affect their perception of school-based agricultural education. It is important to point out that legislators prefer to receive information about school-based agricultural education through different media outlets.

The qualitative analysis also concluded that legislators prefer to receive news through different media sources. The legislators would prefer to receive an email, phone call, or letter if a constituent or organization in their district received an award. If agricultural education programs are going to promote their events to legislators, it is recommended they use mixed media methods to communicate their events to ensure a higher perception of school-based agricultural education.

\section{Research Question 4}

The fourth research question for the study was: Is there a relationship between the legislator's background experiences with farming on their perception of agriculture? The null hypothesizes with research question four were: (17) there is no significant difference in the 
legislators' perceptions of agriculture based on whether the legislator lived on farm and (18) there is no significant difference in the legislators' perceptions of agriculture based on whether the legislator worked on a farm.

The analysis demonstrated no significant differences between legislators living and working on a farm and their perception of agriculture. The researcher believed there was going to be a significant difference; however, that was not the case.

Working or living on a farm did not affect the legislator's perception of agriculture. The literature did not discuss the legislator's perception of agriculture to their experience being around agriculture. However, the researcher speculated that being exposed to different agriculture activities would result in a significantly different perception score compared to legislators not exposed to various agriculture activities.

\section{Research Question 5}

The fifth research question for the study was: Is there a relationship between the legislator's background experiences with farming on their perception of school-based agricultural education? The null hypothesizes with research question five were: (19) there is no significant difference in the legislators' perceptions of school-based agricultural education based on whether the legislator lived on a farm and (20) there is no significant difference in the legislators' perception of school-based agricultural education based on whether the legislator worked on a farm.

The analysis demonstrated no significant differences between legislators living and working on a farm and their perception of school-based agricultural education. Like their perception of agriculture, the researcher believed there was going to be a significant difference; however, that was not the case. 
The results of this null hypothesis contradict the findings from the research conducted by Moore (2013). Moore reported that high school principals with experience working with agriculture had a slightly higher perception of school-based agricultural education compared to principals with no experience with agriculture. The researcher believed the exposure to different agriculture activities would affect the legislator's perception of school-based agricultural education, but this was not the case. This finding suggests that a legislator's background experience with working and living does not affect their overall perception of school-based agricultural education.

\section{Recommendations}

The following recommendations are offered for practice and further research as related to the findings of this study.

Recommendations for Marketing School-Based Agricultural Education Programs to Legislators

Recommendation 1. The results indicate that legislators are unaware of the type of curriculum taught in urban and rural school-based agricultural education programs. During the interviews, all the legislators believed that rural programs focus on production agriculture practices and $25 \%$ of the legislators thought urban programs focused more on community gardening. This does not reflect what is taught in school-based agricultural education programs. School-based agricultural education programs should create a one-page summary of their program and explain what classes are offered and describe the demographic characteristics of their program. It should also include how school-based agricultural education impacts their constituents, total revenue created by the students' Supervised Agricultural Experience programs, and the graduation rates of students enrolled in school-based agricultural education programs. These reports are similar to the National Association of Agricultural Education state 
profiles. These reports will give the legislators an insight of what is taught in urban and rural agriculture programs. Statewide teacher organization such as Illinois Association of Vocational Agriculture Teachers and Illinois Association of Career and Technical Education can help with the implementation of this project.

Recommendation 2. The research found that a legislator's perception changed if they received information about school-based agricultural education through different media channels. Specifically, their perception changed if they received more information about schoolbased agriculture on Facebook, Twitter, and invitations to school-based agricultural education events. The researcher recommends marketing their events on social media as well as sending paper copies of their events to the legislators. This will give the opportunity for the legislators to see what school-based agricultural education events are happening through different media sources.

Recommendation 3. The researcher recommends that the Illinois Association of Vocational Agriculture Teachers create a Freshman Legislative Program that brings freshman legislators out to different agriculture programs and they demonstrate what is happening in their classroom. This would give all legislators an opportunity to see what urban and rural schoolbased agriculture programs look like as well as learn how the agriculture programs benefit the local and state economies

Recommendation 4. The researcher also recommends that the Illinois Association of Vocational Agriculture Teachers create a quarterly newsletter that is distributed to all state legislators that highlights the diversity of agricultural education programs and classroom courses in the state of Illinois. This would give the legislators the change to see the diversity of 
programs across the state. It would also give the legislators a chance to visualize how agricultural education programs benefits students in urban and rural environments.

\section{Recommendations for Future Research}

First, a repeat of this research needs to occur. Due to the low responses rate, this research could not generalize to the larger population of the Illinois General Assembly or legislators in general. Improvements for this research are listed below.

Future research needs to look at more factors that contribute to a legislator's perception of school-based agriculture education. This study only looked at six factors even though there were many more that were listed in the literature. Including more factors may allow future researchers to run a regression model on more factors affecting their perception.

Future research should be conducted during a non-election year. Election year is a busy time for many legislators, and they are focusing a lot of time and efforts on getting re-elected so researching on a non-election year may give a better response rate. Future research should also note lengthy questionnaires are not effective for elected officials. Keep the questionnaires short and concise, so that they can be completed in a short amount of time.

Future research needs to be conducted to examine the perception of $4-\mathrm{H}$ and Cooperative Extension in Illinois. 4-H and Cooperative Extension have had the same budget issues as schoolbased agricultural education. One thing that is different about Cooperative Extension is they receive county funding as well as state and federal funding. It would be beneficial to see how county elected officials perceive the cooperative extension.

\section{Summary}

This chapter included a summary of the study, which included relevant literature, methodology, and findings. It also included conclusions about the findings in relation to the 
research objectives of the study. This chapter concluded with recommendations for school-based agricultural education teachers and supporters and for future research. 


\section{REFERENCES}

Aksan, N., Kisac, B., Aydin, M., \& Demirbuken, S. (2009). Symbolic interaction theory. Procedia Social and Behavioral Sciences, 1(1), 902-909 904.

doi:10.1016/j.sbspro.2009.01.160

Berg, J. (2016). Zero Illinois Agricultural Education Line Item Means Uncertain Future for State's Youth As Illinois Proposes Cutting Long-Term Investment in Agriculture. Retrieved from https://sites.google.com/a/okawvillek12.org/ag/home/ffa/news/zeroingillinoisagricultural educationlineitemmeansuncertainfutureforstatesyouthasillinoisproposescuttinglongterminvestmentinagriculture

Bidner, J. G. (1987). Building Illinois Through Quality Agricultural Education. Retrieved from Urbana, Illinois:

Biffen, R. (1905). Mendel's Laws of Inheritance and Wheat Breeding. The Journal of Agricultural Science, 1(1), 4-48. doi:10.1017/S0021859600000137

Blezek, A. G., \& Dillon, R. D. (1991). Perceptions of Agribusiness Leaders Toward Agricultural Education in Nebraska. The Journal of Agricultural Education, 32, 34-39.

Blumer, H. (1969). Symbolic Interactionism: Perspective and Method (1 ed.). Englewood Cliffs, New Jersey: Prentice-Hall, Inc.

Brodski Schur, J. (2016). Eli Whitney's Patent for the Cotton Gin. Retrieved from https://www.archives.gov/education/lessons/cotton-gin-patent

Bruening, G., \& Lyons, J. M. (2000). The case of the FLAVR SAVR tomato. California Agriculture, 54(4), 6-7. 
Cannizzaro, P. C. (2007). The importance of the Louisiana Cooperative Extension Service as perceived by local governing bodies in Louisiana. (Doctor of Philosophy), Louisiana State University, Baton Rouge, Louisiana.

Carleton, D. (2002). Landmark congressional laws on education. In. Retrieved from https://books.google.com/books?id=DraaG0UyOdIC\&lpg=PP1\&pg=PR4\#v=onepage\&q $\underline{\& \mathrm{f}=\mathrm{false}}$

Creswell, J. W. (2014). Research Design: Qualitative, Quantitative, and Mixed Methods Approaches (4th ed.). Thousand Oaks, California: Sage Publications.

Croom, D. B. (2008). The development of the integrated three-component model of agricultural education. Journal of Agricultural Education, 49(1), 110-120. doi:10.5032/jae.2008.01110

Dimitri, C., Effland, A., \& Conklin, N. (2005). The 20th Century Transformation of U.S. Agriculture and Farm Policy. Washington, D.C. Retrieved from http://www.stefanibardin.net/wp-content/uploads/2016/01/The-20th-Century$\underline{\text { Transformation-of-US-Agriculture.pdf }}$

FFA History. (n.d.). Retrieved from https://www.ffa.org/about/what-is-ffa/ffa-history

Fleischner, M. (2006). Marketing to Generation X. Retrieved from https://www.powerhomebiz.com/marketing-tips/marketing-strategies/generation-x.htm FY17 Final Appropriations and FY18 Enacted Appropriations. (2017). Executive Office of the Governor

Gioia, M., Weberg, B., Ballou, B. J., Powell, L., \& Santos, R. (2015). Legislator Demographics. Retrieved from Washington, D.C.: http://www.ncsl.org/research/about-statelegislatures/who-we-elect-an-interactive-graphic.aspx 
Hatch Act of 1887. (2017). Hatch Act of 1887, 1.

Hillison, J. (1996). The Origins of Agriscience: Or Where Did All that Scientific Agriculture Come from? Journal of Agricultural Education, 37(4), 8-13.

Hirschi, F. W. (1969). The relationship of selected variables to the voting record of Idaho legislators on public school legislation. (Ed.D.), Utah State University, Ann Arbor. (7002436)

Historical Timeline--17th-18th Centuries. (2014). Retrieved from https://www.agclassroom.org/gan/timeline/17_18.htm

Historical Timeline--Crops and Livestock. (2014). Retrieved from https://www.agclassroom.org/gan/timeline/crops_livestock.htm

Historical Timeline--Farm Machinery and Technology. (2014). Retrieved from https://www.agclassroom.org/gan/timeline/farm_tech.htm

Hodson, P. B. (1998). Analysis of perceptions of the 1997 Louisiana legislature toward the Louisiana cooperative extension service. (Doctor of Philosophy), Louisiana State University, Baton Rouge, Louisiana.

Hoffman, S. (2015). Ag education line item could be cut. Retrieved from http://www.journalrepublican.com/news/agriculture/2015-03-03/ag-education-line-item-could-be-cut.html

ILCAE \& ICAE. (n.d.). Retrieved from http://agriculturaleducation.org/Partner-Websites1/ILCAE-ICAE

Illinois Legislative Glossary. (n.d.). Retrieved from http://www.ilga.gov/legislation/glossary.asp\#L 
Illinois State Budget: Fiscal Year 2018. (2017). Springfield, Illinois: State of Illinois Retrieved from https://www.illinois.gov/gov/budget/Documents/Budget\%20Book/FY2018\%20Budget\% 20Book/FY2018OperatingBudgetBook.pdf

Ivancevic, T., Jovanocis, B., Jovanovic, S., Djukic, N., \& Lukman, A. (2011). Paradigm Shift for Future Tennis. In.

Keller, A. G., \& Bishop, A. L. (1912). Commercial and industrial geography. In (pp. 357). Retrieved from https://books.google.com/books?id=eEsAAAAAYAAJ\&pg=PP1\#v=onepage\&q\&f=false

Kruskal-Wallis H Test using SPSS Statisitcs. (n.d.). Retrieved from https://statistics.laerd.com/spss-tutorials/kruskal-wallis-h-test-using-spss-statistics.php Lindner, J. R., Murphy, T. H., \& Briers, G. E. (2001). Handling Nonresponse in Social Science Research. Journal of Agricultural Education, 42(4), 43-53. doi:10.5032/jae.2001.04043

Mann-Whitney U Test using SPSS Statistics. (n.d.). Retrieved from https://statistics.laerd.com/spss-tutorials/mann-whitney-u-test-using-spss-statistics.php

Matlin, M. W. (1983). Perception. Boston, Massachusetts: Allyn and Bacon.

Mazzoni, T., Jr., Sullivan, B., \& Sullivan, B. (1983). Legislative lobbying for education. Planning and Changing, 14(4), 226-233.

Millspaugh, S. (2016). Report for the Committee for Clarification of Official Dress and Related Policies. Retrieved from Indianapolis, Indiana: https://www.ffa.org/SiteCollectionDocuments/delegate_official_dress_reportfinal.pdf\#se $\underline{\operatorname{arch}=o f f i c i a l \% 20 d r e s s}$ 
Moore, A. J. (2013). Perceptions of Kentucky Secondary School Principals About Agricultural Educations Programs: A Comparison of Schools With and Without Agricultural Education Programs. (Doctor of Education), Western Kentucky University, Bowling Green, Kentucky.

National FFA Organization Records, 1916-2008. (2017). Retrieved from https://archives.iupui.edu/handle/2450/142

Novel, J. (2009). Implementation of the Carl D. Perkins Career Technical Education Reforms of the 1990's Postsecondary Education Outcomes of Students Taking an Enhanced Vocational Curriculum. (Doctor of Philosophy), The Ohio State University, Columbus, Ohio.

Oden, D. (2009). Froelich, John. The Biographical Dictionary of Iowa. Retrieved from http://uipress.lib.uiowa.edu/bdi/DetailsPage.aspx?id=128

Patterson, S. C. (1983). Politics in the American States: A comparative analysis (H. Jacob \& K. Vines Eds. 1st ed.). Boston, MA: Little Brown.

Paul Berg - Biographical. (2014). Retrieved from https://www.nobelprize.org/nobel_prizes/chemistry/laureates/1980/berg-bio.html

Phipps, L. J., Osborne, E. W., Dyer, J. E., \& Ball, A. (2008). Handbook on Agricultural Education in Public Schools (6 Ed.). Clifton Park, NY: Delmar.

Robertson, S. D., Durtan, S. J., \& Barham, F. E. (1992). Influence that shape state legislators education policy decision. ERS Spectrum, 10(1), 30-33. 
Russell, R. (2016). Perceptions of Secondary Agricultural Education Programs, The National FFA Organization, and Agricultural Careers of Students Not Enrolled in a High School Agricultural Course. (Masters of Science), University of Kentucky, Lexington, Kentucky.

Scott, F. L., \& Lavergne, D. (2004). Perceptions of Agriculture Students Regarding the Image of Agriculture and Barriers to Enrolling in an Agriculture Education Class. Journal of Southern Agricultural Education Research, 54(1), 48-59.

Scott, J. L., \& Sarkees-Wircenski, M. (2004). Overview of Career and Technical Education (3rd ed.). Homewood, Illinois: American Technical Publishers.

Smith-Hughes National Vocational Education Act of 1917, P.L. 62-347, House of Representatives, 64 Cong. Rec. $39 \S 18$ (1917).

Social Media Fact Sheet. (2018). Retrieved from http://www.pewinternet.org/fact-sheet/social$\underline{\text { medial }}$

Taylor-Powell, E., \& Renner, M. (2003). Analyzing Qualitative Data. Retrieved from Madison, Wisconsin:

The Story of U.S. Agricultural Estimates. (1969). Washington, D.C.: U.S. Government Printing Office Retrieved from https://books.google.com/books?id=8R0uAAAAYAAJ\&pg=PR1\#v=onepage \&q\&f=false

Timmons, F. L. (1970). A History of Weed Control in the United States and Canada. Weed Science, 18(2), 294-307.

Total Population Sampling. (2012). Retrieved from http://dissertation.laerd.com/total-populationsampling.php 
Understanding the CASE Model. (2012). Retrieved from

http://case4learning.org/images/documents/Understanding\%20the\%20CASE\%20Model \%281\%29.pdf

Uricchio, C., Moore, G., \& Coley, M. (2013). Corn Clubs: Building the Foundation for Agricultural and Extension Education. Journal of Agricultural Education, 54(3), 224237. doi:10.5032/jae.2013.03224

Vanderveer, N. J. (1980). Ecological acoustics: Human perception of environmental sounds. (40), ProQuest Information \& Learning, US. Retrieved from http://libproxy.lib.ilstu.edu/login?url=https://search.ebscohost.com/login.aspx?direct=true

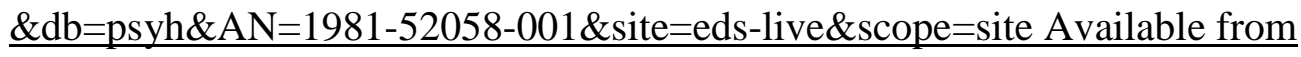
EBSCOhost psyh database.

Wachenheim, C. J., \& Lesch, W. C. (2002). Public Views on Family and Corporate Farms. Journal of Agricultural and Food Information, 4(4), 43-60.

Wirt, F. M., Morey, R. D., \& Brakeman, L. F. (1970). Industry problems in political research. Englewood Cliffs, NJ: Prentice-Hall.

World's population increasingly urban with more than half living in urban areas. (2014). Retrieved from http://www.un.org/en/development/desa/news/population/worldurbanization-prospects-2014.html 


\section{APPENDIX A: IRB APPROVAL}

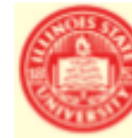

\section{ILLINOIS STATE} UNIVERSITY

IIlinois' first public unicersity
Research Ethics and Compliance

Campus Box 3330

Normal, IL 61790-3330

Phone: (309) 438-2528

rec.0illinois Stateedu

$\begin{array}{ll}\text { DATE: } & \text { November 13, } 2017 \\ \begin{array}{l}\text { TO: } \\ \text { FROM: }\end{array} & \begin{array}{l}\text { Richard Steffen, PhD } \\ \text { Illinois State Univers }\end{array} \\ \text { PROJECT TITLE: } & \begin{array}{l}\text { [1146568-1] Illinois L } \\ \text { Agricultural Education }\end{array} \\ \text { SUBMISSION TYPE: } & \text { New Project } \\ \text { ACTION: } & \text { APPROVED } \\ \text { APPROVAL DATE: } & \text { November 13, 2017 } \\ \text { REVIEW TYPE: } & \text { Exempt Review }\end{array}$

Thank you for your submission of New Project materials for this project. The Illinois State University IRB has APPROVED your submission. This approval is based on an appropriate risk/benefit ratio and a project design wherein the risks have been minimized. All research must be conducted in accordance with this approved submission.

This submission has received Exempt Review based on applicable federal regulations.

Please remember that informed consent is a process beginning with a description of the project and insurance of participant understanding followed by a signed consent form. Informed consent must continue throughout the project via a dialogue between the researcher and research participant. Federal regulations require that each participant receives a copy of the consent document.

Please note that any revision to previously approved materials must be approved by this committee prior to initiation. Please use the appropriate modification forms for this procedure.

All UNANTICIPATED PROBLEMS involving risks to subjects or others (UPIRSOs) and SERIOUS and UNEXPECTED adverse events must be reported promptly to this office. Please use the appropriate reporting forms for this procedure. All sponsor reporting requirements should also be followed.

All NON-COMPLIANCE issues or COMPLAINTS regarding this project must be reported promptly to this office.

Please note that all research records must be retained for a minimum of three years after the completion of the project.

If you have any questions, please contact Research Ethics and Compliance at 309-438-2529 or rec@ilstu.edu. Please include your project title and reference number in all correspondence with this committee.

This letter has been electronically signed in accordance with all applicable regulations, and a copy is retained within Illinois State University IRB's records. 


\section{APPENDIX B: COVER LETTER}

\section{Dear (LEGISLATOR'S NAME),}

The Department of Agriculture at Illinois State University is asking for your help in a research study to assess Illinois legislator's perceptions of agriculture and school-based agricultural education in Illinois. This study is an effort to see how state legislators view school-based agricultural education and how often they heard about school-based agricultural education. To accomplish this mission, we need feedback from the legislators to help us improve the perception of school-based agricultural education in Illinois.

This study will examine four different factors: demographics, perception of agriculture and school-based agricultural education, and the frequency of how often you hear about school-based agricultural education. The study will start with a questionnaire that will take approximately 1015 minutes. After the questionnaire, you will have the opportunity to participate in the phone interview section of the study. While your responses would help strengthen the research data, you may choose to not participate in this study. Not everyone will be asked to participate in the interviews. Your questionnaire responses will be linked to the interviews questions.

The online questionnaire will take approximately 10-15 minutes. We would appreciate it if you completed the questionnaire by December $26^{\text {th }}$. To begin the questionnaire please click the on the following link:

\section{https://illinoisstate.az1.qualtrics.com/jfe/form/SV_cGVkR3tMK5Zhh0F}

After completing the questionnaire, you will be asked if you would like to participate in the phone interview section of the research. If you are not interested in the interview, you may exit out of the questionnaire. If you choose to participate in the interview, we will ask you to provide your email address so we able to contact you for follow up interview questions. Again, not everyone will be asked to participate in the interviews.

Your identity will remain confidential; after all data have been collected, the questionnaires and interviews responses will be destroyed. If you participate in the interview, your questionnaire responses will be linked to the interview questions that may contain personal identifiers. We do not anticipate that this study will you subject to any risks greater than those you would normally encounter in everyday life. There are no benefits or compensation to you for participating in the study. Should you have any questions, please contact us by phone at <omitted> or by email at <omitted>.

Thank you for your time and consideration,

Sincerely,

Dick Steffen

Professor of Agricultural Education
Perry W Harlow

Graduate student 


\section{APPENDIX C: QUESTIONNAIRE CONSENT}

Dear Illinois Legislator,

You are invited to take part in a research study about Illinois legislators' attitudes and perceptions of agriculture and school-based agricultural education. The purpose of the research is to inform school-based agricultural education supporters about elected officials' views of school-based agricultural education in Illinois. Your participation will require approximately 10-15 minutes and is completed online at your computer.

There are no known risks, benefits, or compensation provided to you for participating in this study. Taking part in this study is completely voluntary. Your responses will be kept strictly confidential, and digital data will be stored in secure computer files. Any report of this research that is made available to the public will not include your name or any other individual information by which you could be identified.

If you prefer not to respond, please let us know by selecting the box that reads, "I do not give consent to participate in this study." Selecting the box that reads, "I do give consent to participate in this study" acknowledges your consent to participate in this study and will automatically direct you to the survey. You may withdraw from the survey at any time by closing your web browser. You may discontinue participation at any time without penalty or loss of benefits. 
If you have questions or want a copy or summary of this study's results, you can contact the researcher, Richard Steffen, at <omitted>. In addition, for questions about research participants' rights and/or a research related injury or adverse effects, please contact the Research Ethics \& Compliance Office: <omitted> and/or <omitted>. Please feel free to print a copy of this consent page to keep for your records.

Richard Steffen

Professor of Agricultural Education

Perry Harlow

Graduate Student 


\section{APPENDIX D: CONSENT FOR INTERVIEW}

Thank you for completing my questionnaire! Your responses are going to benefit my research. I would like to strengthen my research by conducting individual interviews. You are invited you to participate in the interview section of the research. Your participation will require approximately 10-15 minutes and this will be completed through phone interviews.

There are no known risks benefit or compensation to you for participating in this interview. There are no personal benefits of this. Taking part in this study is completely voluntary. Your responses will be kept strictly confidential and will be stored in secure computer files. Any report of this research that is made available to the public will not include your name or any other individual information by which you could be identified.

If you prefer not to respond, please let us know by selecting the box that reads, "I do not give consent to participate in the interview." Selecting the box that reads, "I do give consent to participate in the interview" acknowledges your consent to participate in the interview. You may discontinue participation at any time without penalty of loss of benefits.

If you have questions or want a copy or summary of this study's results, you can contact the researcher, Richard Steffen, at <omitted>. In addition, for questions about research participants' rights and/or a research related injury or adverse effects, please contact the Research Ethics \& Compliance Office: <omitted> and/or <omitted>. Please feel free to print a copy of this consent page to keep for your records.

Perry Harlow

Graduate Student 


\section{APPENDIX E: QUESTIONNAIRE}

1. How old are you?

2. What is your gender?

Male

Female

Choose not to disclose

3. What race do you identify with? Please select all that apply.

Asian/Pacific Islander

Black or African American

Hispanic or Latino

Native American or American Indian

White

Other

Choose not to disclose

4. What is the highest education/degree you have received?

High school diploma/GED

Vocational/career certificate 
Associate's degree

Bachelor's degree

Master's degree (for example: MA, MS, MEng, MEd, MSW, MBA)

Professional degree (for example: MD, DDS, DVM, LLB, JD)

Doctorate Degree (for example: $\mathrm{PhD}, \mathrm{EdD}$ )

5. How many years of service do you have as a state legislator?

6. What is your primary occupation/profession (e.g. lawyer, business owner, etc.) in addition to your role as a state legislator?

7. Which of the following best describes... (please respond to both)

\begin{tabular}{|c|c|c|c|c|}
\hline $\begin{array}{l}\text { Rural living } \\
\text { on a farm }\end{array}$ & $\begin{array}{l}\text { Rural not } \\
\text { living on a } \\
\text { farm }\end{array}$ & $\begin{array}{l}\text { Town ( } 1 \text { to } \\
9,999 \text { in } \\
\text { population }\end{array}$ & $\begin{array}{l}\text { Suburban } \\
(10,000- \\
49,999 \text { in } \\
\text { population })\end{array}$ & $\begin{array}{l}\text { City }(50,000 \\
\text { and over in } \\
\text { population) }\end{array}$ \\
\hline
\end{tabular}

the place you

grew up (0-

18 years of

age)?

the district

you

represent?

8. Which region of Illinois best describes the majority (75\%) of your district?

Cook/Collar Counties (DuPage, Kane, Lake, McHenry and Will)

West of Illinois Route 47 and North of Interstate 80 
South of Interstate 80 and North of Interstate 70

South of Interstate 70

9. Have you ever... (please respond to both)

Yes No

lived on a farm?

worked (full-time) on a farm?

10. Were you involved in agricultural youth organizations growing up? Please check all that apply.

National FFA Organization (formally known as Future Farmers of America)

4-H

Other (please specify)

11. Did you take any agriculture-related classes in... (please respond to both) high school?

Yes No

college?

12. How many school-based agricultural events (FFA activities) have you attended since January 1st, 2017?

13. What is the first word you think of when you see the word "agriculture?" 
14. This section is designed to measure your perception concerning the agriculture industry in Illinois. For each of the statements listed, please mark the appropriate response.

Strongly
Disagree

Disagree

Agriculture is

a part of my

everyday life.

Agriculture is important to

my

community.

The economic impact of agriculture is important for the State of Illinois.

The food produced by farmers in Illinois is safe.

A career focused in agriculture is a good choice for young people.

Farmers are concerned about the environmental impact of farming.

Most farmers in Illinois get
Neither

Agree nor

Disagree
Agree

Strongly

Agree 
the majority

of their

income from

their farm.

15. What is the first word you think of when you hear the word "agricultural education?"

16. This section is designed to measure your perception concerning school-based agricultural education. For each of the statements listed, please mark the appropriate response.

\begin{tabular}{|c|c|c|c|}
\hline $\begin{array}{l}\text { Strongly } \\
\text { Disagree }\end{array}$ & Disagree & $\begin{array}{l}\text { Neither } \\
\text { Agree nor }\end{array}$ & Agree \\
\hline & & Disagree & \\
\hline
\end{tabular}

School-based

agricultural

education is a

valuable asset

to local

communities.

School-based

agricultural

education is

an important

resource for

local

communities.

School-based

agricultural

education

plays an

integral role

in improving

the lives of

school-aged

residents.

The student

organization

connected to

school-based

agricultural 
education

(FFA) is very

important for

the

development

of our school

aged

residents.

The

curriculum

taught in

school-based

agricultural

education is

focused only

on production

agriculture.

Students from

urban

backgrounds

benefit from

school-based

agricultural

education.

Students from

rural

backgrounds

benefit from

school-based

agricultural

education.

Both rural

and urban

students

should have

equal access

to school-

based

agricultural

education. 
School-based

agricultural

education

programs

have

experienced a

decline in

enrollment

state-wide.

17. The amount of money allocated in the yearly budget to school-based agricultural education is...

Too low

Just right

Too high

18. This section is designed to measure how often you have heard, seen or received

information from or about school-based agricultural education in Illinois. For each of the information sources listed, please marked the appropriate response to indicate how often you have heard, seen or received the information.

$\begin{array}{llllll}\begin{array}{l}\text { None at } \\ \text { all }\end{array} & \begin{array}{l}\text { Rarely } \\ (1-2\end{array} & \begin{array}{l}\text { Occasionally } \\ \text { (3-5 times a }\end{array} & \begin{array}{l}\text { Moderately } \\ (6-11 \text { times }\end{array} & \begin{array}{l}\text { Monthly } \\ (12 \text { or }\end{array} & \begin{array}{l}\text { Does not } \\ \text { apply to }\end{array} \\ & \text { times a } & \text { year }) & \text { a year }) & \begin{array}{l}\text { more } \\ \text { times a }\end{array} & \text { me } \\ & \text { year }) & & & \text { year }) & \end{array}$

Programs or news

stories mentioning

school-based

agricultural

education on the

radio.

Programs or news

stories mentioning

school-based

agricultural

education on TV.

News

stories mentioning 
school-based

agricultural

education

in newspaper

articles.

Programs or news

stories mentioning

school-based

agricultural

education on

Facebook.

Programs or news

stories mentioning

school-based

agricultural

education on

Twitter.

Programs or news

stories mentioning

school-based

agricultural

education on

Instagram.

Personal contacts

from constituents

in schools-based

agricultural

education

programs (i.e. Ag

Day at the

Capitol, personal

office visits, etc.)

Family members

and FFA alumni

members involved

in school-based

agricultural

education.

Illinois

Agricultural 
Education

website.

Invitation to

school-based

agricultural

education

activities.

19. Please list any other information sources. 


\section{APPENDIX F: INTERVIEW QUESTIONS}

\section{Demographics}

1. Growing up, how did people view agriculture in your household?

a. Who was informing you about the agriculture topics?

2. Were their agriculture classes available for you to take at your high school?

a. Would you have taken them if they were available?

b. Did anyone ever discourage you from pursing a degree in agriculture?

3. If you can recall, what was the farm economy like when you were growing up?

4. What type of agriculture businesses are in your district?

5. How does agriculture impact your life on a daily basis?

SBAE Perception

6. Are you familiar with the type of agriculture classes are currently taught in rural agriculture programs?
a. Do you know what topics are discussed?

7. Are you familiar with the type of classes are currently taught in urban agriculture programs?

a. Do you know what topics are discussed?

\section{Media Sources}

8. How do you rely on media to gain knowledge on topics?

9. What is your favorite media platform to hear or see what events are happening in your community? Does not have to be a social media platform.

10. If one of your constituents or organizations in your district won an award, how would you like to be informed about it? 
11. How would you prefer your constituents to contact you about issues that are concerned about? 


\section{APPENDIX G: INTERVIEW RESPONSES}

\section{Demographics}

Growing up, how did people view agriculture in your household?

I remember agriculture as food and the smell of the onion fields by our house.

Our family discussed growing food in local communities. Great grandmother had garden and so did my grandfather. Even my dad had one! We talked more about community gardens than agriculture.

We did not talk about agriculture in our home growing up. We grew up in the suburbs and didn't talk about it that much.

I grew up in a suburban region of Cincinnati. We had family in Indiana that farmers and we would visit them every once in a while. Our family has a small backyard garden.

Who was informing you about the agriculture topics?

I was informed by my parents and extracurricular activities.

We didn't talk about them per say. It wasn't a normal conversation because we were from the inner city of Chicago. It was not talked about.

No.

Nope. Not anything that I could think of.

Were there agriculture classes available for you to take at your high school?

Yes

No there were not.

I am not sure if they were available for me to take.

No

Would you have taken them if they were available?

Yes

I believe so. Especially because the school have a beautiful greenhouse but the CPS (Chicago

Public Schools) had a lack of funding and it eventually went away. I would have participated if available.

I am not sure; possibly.

Probably not. Limited number of extra electives I could take and I was focusing more on the arts options.

Did anyone discourage you from pursing a degree in agriculture?

No.

No.

No. No one encouraged me or discouraged me from pursuing a career in agriculture. Nope.

If you can recall, what was the farm economy like when you were growing up?

Can't recall but we lived in a very active onion farming community. There were a lot of farms being sold to development but there was complaints coming from the suburban area about the smell of the onions.

I would not be familiar with it.

I grew up in Wheaton, Illinois. Our family drove by farms all of the time and I remember being exposed to them but now they are just shopping malls. But there was a quite a bit of farms. 
It was not the greatest for farmers. During that time period, there was a lot of concerns. Many people were losing their farm. I remember that there were rock concerts happening to help support the farmers. It was not a strong industry at the time.

What type of agriculture businesses are in your district?

Yes, grocery stores.

We have an urban farm. There are some agriculture businesses.

None.

We have a Marijuana dispensary in our district. We also see many farmers markets and we also have a 1880 s demonstration farm.

How does agriculture impact your life on a daily basis?

By every single means. Agriculture does a lot for the economic development in my district. Obviously from a nonfarm perspective, local farms provide access to food. There is also a lot of community farming that takes place. My district has many centennial farms and it is an integral part of our community.

I feel that agriculture is connected to food insecurity. Agriculture is something that we are looking towards to have better food access and have it be more economical for people living in the city they can afford.

We have some farmers markets and farmers who sell their products that are locally grown. Agriculture would impact me by my general food consumption. I eat every day, but I cannot think of any other factors.

By all of the food I eat. Agriculture is huge! Everything comes pre-packaged, so we don't think about where it comes from anymore.

\section{School-Based Agriculture Education Perception}

Are you familiar with the type of agriculture classes they are currently taught in rural agriculture programs?

Yes

I am familiar with some programs. I actually have been on a tour of what some classrooms are like. But I don't know a whole, whole lot.

No.

A little bit.

Do you know what topics are discussed?

I see a lot of the curriculum as seed to table. It explains everything from a grain perspective to dairy cattle and pig perspective. It also discusses how agriculture is important to daily lives. Some other topics include the use of chemicals and fertilizers and the use of GMO's. I see a lot of field trips.

For the most part, they dealt with maintenance and operation of livestock or plants. The teachers taught students how to take care of those different types of operations. The students had a lot of opportunities to have hand on experience for real agriculture careers. These experiences gave students some exploration of what careers are available in agriculture. Some of the classes would be agriculture management, philosophy of agriculture, soil programs, and seed programs that focus on GMO technology. Agriculture is Multi-verse discipline that can be discussed from many different angles.

It would cover quite a range. A lot of it is science and technology based. How seeds can be hybridized and fights off insects. New methods of what for what your soils need to let it 
remain healthy. Environmental component of how pesticides can be. More sophisticated that just putting a seed in the grown and letting it grow.

Are you familiar with the type of classes that are currently taught in urban agriculture programs?

Yes

Again, some idea.

No.

Not really.

Do you know what topics are discussed?

I see it very similar to the rural agriculture programs but Less on economic perspective. It would have the same perspective as seed to table concept.

They (CPS) has CHSAS (Chicago High School for Agricultural Sciences and they are very well known. Have the largest FFA chapters in the state, I can recall. They do a lot of the same training as rural programs. There were some urban elements.

Some of the topics discussed could be non-traditional farming techniques and how to maximize space with small spaces. Garden is a hobby and farming is like a profession.

Another thing option could be how to grow food in maximum number of volume in a small space.

More of a focus on animal care. But similar to rural programs.

Media Sources

How do you rely on media to gain knowledge on topics?

Very little.

I rely on media somewhat to gain knowledge. I used to be a member of the media and left the business because there were somethings that I did not agree with it. I watch it to see what is happening. I am careful how it influences people and see how much they put into the coverage.

I rely on media a lot for my information.

Read a lot of articles. Not great keeping up with Facebook that younger people keep up with.

What is your favorite media platform to hear or see what events are happening in your community? Does not have to be a social media platform.

Radio more than anything. Some social media and email. Farm Bureau sends stuff all of the time.

In my community, the internet and social media is the best for my community. Face to face community is key. Communication is strange in our community so social media and internet is the best for us.

I get it from all over but the most common are newspaper and social media.

Newspaper. People send people direct invitations to our office and I look at them.

If one of your constituents or organizations in your district won an award, how would you like to be informed about it?

Via email.

I liked to be informed by a phone call or email. If we get them through those two channels, I think that is good.

I prefer message sent to the district office either phone call or by a letter. We will follow up by a phone call.

Letter or email. 
How would you prefer your constituents to contact you about issues that they are concerned about?

Email.

I prefer to call my office. Send an email is okay but if they call, I prefer that.

Which every way is most convenient for them; Phone call, email, or a message on social media.

Whatever makes them most comfortable. Facebook, to text to hand letter, in person, phone call. Whatever makes it easier for them voicing their opinion so they do it more often. 


\section{APPENDIX H: QUESTIONNAIRE PERMISSION}

\section{Re: Survey Permission}

\section{Peter Cannizzaro}

Sun 9/10/2017 5:59 PM

To: Harlow, Perry;

You certainly have my permission, yes. Let me know if I can help you further. Thanks. Dr. Peter cannizzaro

Sent from my iPhone

On Sept 8, 2017, at 3:50 PM, Harlow, Perry wrote:

Good afternoon Mr. Cannizzaro-

I am Perry Harlow and I am a graduate student at Illinois State University majoring in Agricultural Education and Leadership. I came across your research on the importance of the LCES as perceived by local governing bodies in Louisiana. I am researching Illinois Legislators perceptions and attitudes of school-based Agricultural Education. Do I have your written permission to use a modified version of your survey design on my research? I also have reached out to Dr. Hudson to have her permission as well.

Thank you,

Perry Harlow

Illinois State University 


\title{
Re: Survey Design Permission
}

\author{
Hodson, Pamela \\ Wed 9/6/2017 7:19 PM \\ To:Harlow, Perry; \\ Perry, \\ Yes, you may modify the survey for your research. Good luck! \\ Pam
}

Pamela B. Hodson, PhD

LSU AgCenter/LA Sea Grant

Sent from my iPhone

On Sep 6, 2017, at 3:03 PM, Harlow, Perry wrote:

Good Afternoon Dr. Hodson-

I am Perry Harlow and I am a graduate student at Illinois State University majoring in Agricultural Education and Leadership. I came across your research when I found Dr. Peter Cannizzaro's research on the Importance of the LCES as perceived by local governing bodies in Louisiana. I am researching Illinois Legislators perceptions and attitudes of Agricultural Education. Do I have your written permission to use a modified version of your survey design on my research?

Thank you,

Perry Harlow

Illinois State University 